\title{
The North or the South? Early medieval ceramics decorated with a zoned ornament - the result of local changes or interregional contacts?
}

\author{
Sever či jih? Raně středověká keramika s pásovou výzdobou - \\ výsledek lokálního vývoje nebo meziregionálních kontaktů?
}

\author{
Justyna Kolenda - Kinga Zamelska-Monczak
}

\begin{abstract}
The article underlines the need to re-discuss the prevailing views in archaeological literature on the provenance and transformation stages of completely wheel-turned ceramics decorated with zoned ornament ${ }^{1}$. This class of ceramics was used in the Early Middle Ages (for about 100 years) by communities living in the area of southern Greater Poland and the north-eastern part of Lower Silesia. The previous ideas suggesting a close relationship between zoned ceramics and vessels produced in northern Bohemia are reconsidered, with the internal diversity of zoned ceramics being pointed out. We argue that inspiration in ceramics manufacturing came not only from the south (Bohemia), but also from the north (Pomerania) and the west (the middle Elbe region), and that there were also changes that appeared independently of these impulses in the ceramics production of small, native communities.
\end{abstract}

wheel-turned ceramics - zoned vessels - early medieval pottery - southern Greater Poland - Lower Silesia Bohemia

Studie otevírá diskusi s názory o původu a vývojových proměnách keramiky vytáčené kompletně na hrnčířském kruhu a opatrené pásovou výzdobou. Tato keramická tř́da byla používána v raném středověku (po dobu asi jednoho století) komunitami žijícími na jihu Velkopolska a v severovýchodní části Dolního Slezska. Dosavadní představy naznačujicí úzký vztah s obdobně zdobenou keramikou produkovanou v severních částech Čech jsou přehodnoceny s poukazem na vnitřní rozmanitost celé keramické trídy. Inspirační zdroje neprícházely pouze z jihu (z Čech), ale také ze severu (Pomořansko) a ze západu (oblast středního Labe). V rámci tohoto druhu keramiky lze pozorovat proměny, které se v produkci malých lokálních komunit objevuji nezávisle na vnějších impulsech.

keramika vytáčená na kruhu - nádoby s pásovou výzdobou - raně středověká keramika - jižní Velkopolsko Dolní Slezsko - Čechy

Professor Wojciech Dzieduszycki in memoriam

\section{Introduction}

The aim of the article is to indicate the need for more extensive research on early medieval zoned ceramics, used mainly in the $10^{\text {th }}$ and at the beginning of the $11^{\text {th }}$ century by communities building and using small strongholds in southern Greater Poland and the north-eastern part of Lower Silesia (the compact range of zoned ceramics is the area between the upper and the middle Obra River and mainly the upper Barycz River: fig. 1, 2).

\footnotetext{
1 In the further part of the article, the term 'completely wheel-turned ceramics decorated with a zoned ornament' is replaced by the term 'zoned ceramics' or 'zoned vessels/pots'.
} 


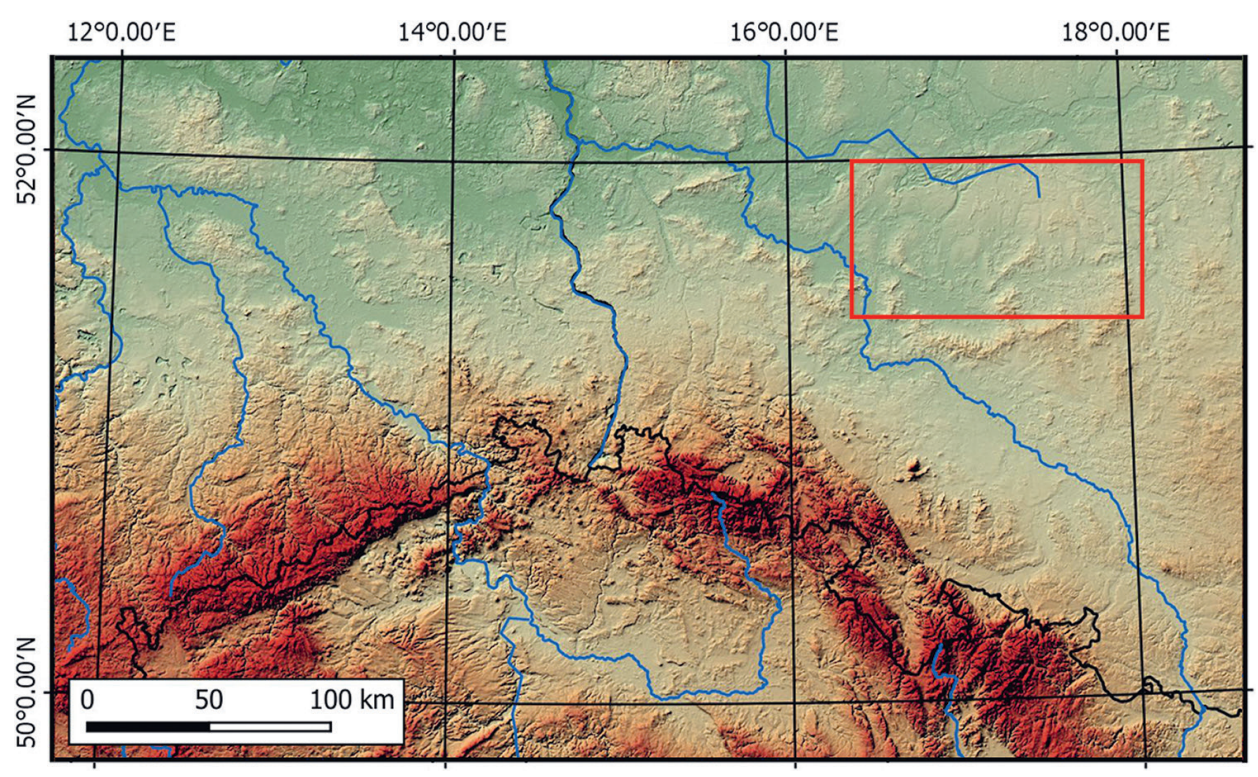

Fig. 1. Location of the research area in Lower Silesia. Prepared by P. Wiktorowicz; elevation data source: copernicus.eu

Researchers from the centre in Poznan associate the building of these strongholds with the process of this area's inclusion within the Piast state. According to Z. Kurnatowska [...] around year 940, the first important stage of state-building had already been completed: the formation and strengthening of the central area, this being the domain of the Piast dynasty with several huge strongholds. [...] At the same time, activities had been taken to expand the territorial basis of the new state (Kurnatowska 2009, 85). These activities resulted in the occupation of the right basin of the Barycz River, with the construction of small strongholds intended to be a manifestation of the Piasts' presence in northern Silesia. As an example, Kurnatowska mentions the stronghold in Kaszowo, built after the year 949, and the settlement complex of Piaski-Rochy, which was to have been built on the basis of a settlement of war prisoners (Kurnatowska 2009, 86). Along with the strongholds in this area, zoned vessels appear as an innovation in traditional ceramics, thus confirming the connection with the state organization.

The impulse to re-analyze the issues related to zoned ceramics arose from the recent results of the analysis of early medieval pottery from sites in Wrocławice (fig. 3, 4), Lelików, Góry, and Milicz, all located in the north-eastern part of Lower Silesia (Kolenda-Zamelska-Monczak 2020). These sites were considered in the context of findings on pottery manufacturing (Kotková 2008; 2009; Kotková - Lange 2010; Meduna 2015; Stoksik-Paternoga 2009; Siemanowska 2017; Paternoga et al. 2017; Kobylińska et al. 2020).

The basic assumption of our considerations relates to the research postulate formulated by W. Hensel. According to this scientist, conclusions regarding the development of ceramics associated with a specific area, while automatically used in the interpretation of groups identified in other areas, make it impossible to correctly determine their transformations (Hensel 1956, 160). In unpacking this view, it should be stressed how difficult it is both 


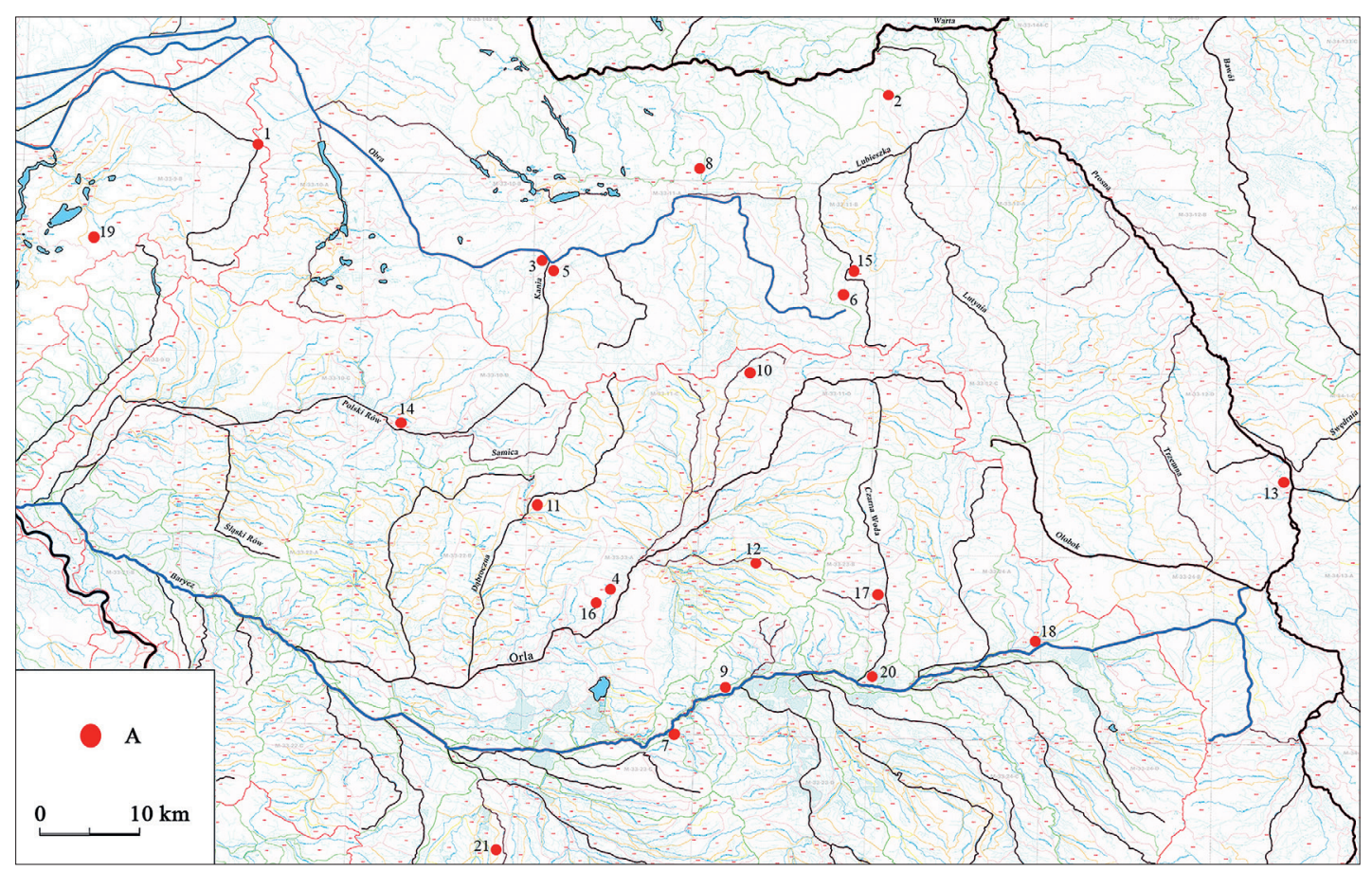

Fig. 2. Map of the study area between the Barycz and Obra Rivers. A - the location of the sites where zoned pottery has been found: 1 - Bruszczewo; 2 - Chrzan; 3 - Daleszyn; 4 - Domaradzice; 5 - Dusina; 6 - Golina; 7 - Kaszowo; 8 - Mchy, 9 - Milicz; 10 - Mokronos; 11 - Niepart; 12 - Piaski-Baszków; 13 - Piwonice; 14 - Poniec; 15 - Siedlemin; 16 - Osiek; 17 - Sulmierzyce; 18 - Topola Wielka; 19 - Włoszakowice; 20 - Wrocławice; 21 - Wszemirów. The source is the Hydrographic Map of Poland made by the Department of Hydrography and Morphology of River Corridors of the Institute of Meteorology and Water Management commissioned by the Minister of the Environment and financed by the National Fund for Environmental Protection and Water Management (the map is available at http://www.kzgw.gov.pl).

to define inspirations coming from other cultural zones and to identify local elements in the development of pottery production. This means that the findings of ceramic assemblages obtained from sites located in the basin of the upper and middle Obra (south-western Greater Poland) cannot be easily and automatically transferred to the territory of the north-eastern part of Lower Silesia or south-eastern Greater Poland. Another assumption relates to the possibilities indicated in the literature for conducting studies on the regional differentiation of ceramics based on stylistic features, which, at a more detailed level, can be used to identify differences between individual local communities (between individual communities occupying small strongholds and rural centres). For our further considerations, two concepts should be clarified: style and local communities.

The concept of style in traditional archaeology is primarily used to establish the formal similarity of artefacts. It is then applied to illustrate the relationship between archaeological assemblages. More recent theories of style propose an extension of the concept of style, treating it as a socio-cultural phenomenon that implies social relations and identifies a given community. Style is a means/method of visual communication (treating style as a form of social communication is also the main assumption of ceramic sociology). The concept proposed by J. Sackett combines two aspects: the functional and stylistic, while not combining 

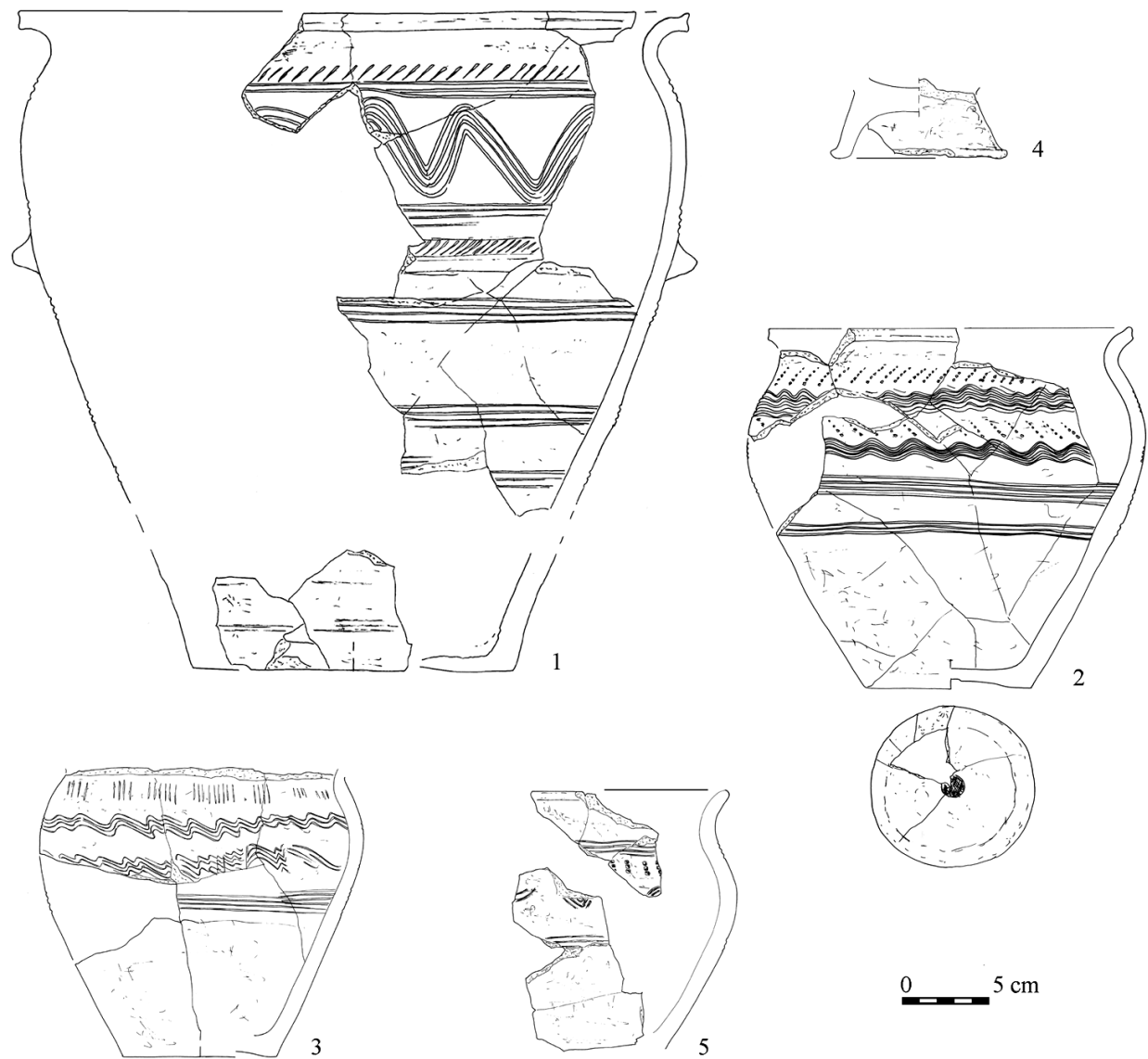

Fig. 3. Wrocławice, site 1, comm. Milicz. A selection of transitional vessels: 1 - storage vessels, 2, 3, 5-pots, $4-$ a cup with the empty leg. Drawings on figs. 3-9 K. Świątek.

style only with the sphere of aesthetics (Kobylińska 1980, 199). Thus, analysis of an artefact's style includes not only decoration, but also the technology and the function of the object. According to M. Wobst (1977), a style is an information carrier, that is, decoration (e.g., on ceramics) and the form of an artefact is the means of transmitting the message. On the other hand, P. Wiessner (1983) treats a style as an "active" factor, as a selection of conscious elements, various types of information, describing it as "emblematic" when referring to entire groups, and as assertive when to the individual or personal sphere (Rice 2015, 404). Therefore, the style of ceramics can be interpreted from differing points of view. According to P. Rice, style in ceramics is a visual image, unique in terms of time and place, transmitting, to varying extent, information about the society that created it, about the producers, and about the context and place of the artist's activity (Rice 2015, 409). At every stage of creating a style, in connection with the function and technology of an object, an important role is played by choice, which embodies individual decisions and the creativity of the creator. In the case of ceramics, this includes decorating a vessel. Limitations in shaping a style also come from the existing, unconscious, cultural frameworks - and this concerns standards, traditions, and customs (Rice 2015, 409, fig. 24.9). We share this view.

Based on the assumptions provided by sociologists, in this article the local community is understood as a group of people living in a specific area, the centre of which is determined by the stronghold, though it is seen not as a defensive object, but as a place organizing the life of a studied community, giving it 
a feeling of community. These communities can also be defined as a face-to-face-society (Hansen 2006, 12). Two categories have been selected for the study of past local communities, as based on archaeological data: territory, as a local community is characterized by a strong sense of belonging to a given area and social interactions of various ranges occurring between individual communities, wherein ceramics has been used as the determinant. Such an understanding of the community may be applied to studies on small strongholds and rural centres existing in the area of south-eastern Greater Poland and north-eastern Lower Silesia.

The analysis of ceramics from strongholds in the north-eastern part of Lower Silesia (Wrocławice, Milicz, Kaszowo) revealed differences in the level of skills and the ornamental composition of zoned pots. This led us to formulate a hypothesis that any new category of ceramics reflects changes taking place in local communities and the resultant need to manifest their group identity (we do not link group identity to ethnicity). The considerations presented in this article raise several questions. Why did the manufacturing of zoned ceramics start in the area between the Obra and Barycz Rivers? Was the production of new quality pots due to external inspirations or direct contacts with potters using more advanced technology, or changes in local manufacture? Was the acceptance and implementation of new technology combined with a different style taking place in the entire analyzed area in the same way and at a similar time, or did this take place gradually, at different periods, as a result of independent contacts between individual communities? The answers to these questions require examination of the phenomena occurring in the area between the upper and middle Obra River and mainly the upper Barycz River in a wider cultural context. Thus, it is justified to re-analyze the provenance and circumstances of the emergence of the new technology of completely wheel-turned by which zoned pots were made. It is also important for such a study to establish potential relationships between potters from the neighbouring areas: southern (Moravia and Bohemia), northern (Greater Poland) and western (mid-Elbe), and the manufacturers of zoned ceramics. Thus, we discuss the view that zoned ceramics appeared in the upper and middle course of the Obra River as a result of impulses from the south (Moravia and Bohemia), and in the upper Barycz Basin under the influence of impulses coming from the centre of the Piast state. In terms of time, the above considerations concern changes in pottery manufacturing mainly in the $10^{\text {th }}$ century.

\section{Influences from the south in the ceramics from the territory of southern Greater Poland and the north-eastern part of Lower Silesia}

One of the first results of the studies on early medieval ceramics from sites located within western Poland indicates its technological, formal and stylistic diversity. Those researchers recognized the differences observed in stylistic diversity as a criterion for dividing cultural phenomena in space. This resulted in discerning two zones: northern and southern, based on differences in ornamentation and vessel forms. The border between the two was established in the area of Greater Poland (Kostrzewski 1949, 257; Kurnatowska 2008, 308, a map). Most of the changes, particularly of a progressive nature (both on technical and formalstylistic levels) within these two zones, were attributed respectively to influences coming from the south or north. Such a division, accepted by archaeologists, resulted also in a sharper perception of the technology and style of vessels in southern Greater Poland and northern Lower Silesia. 

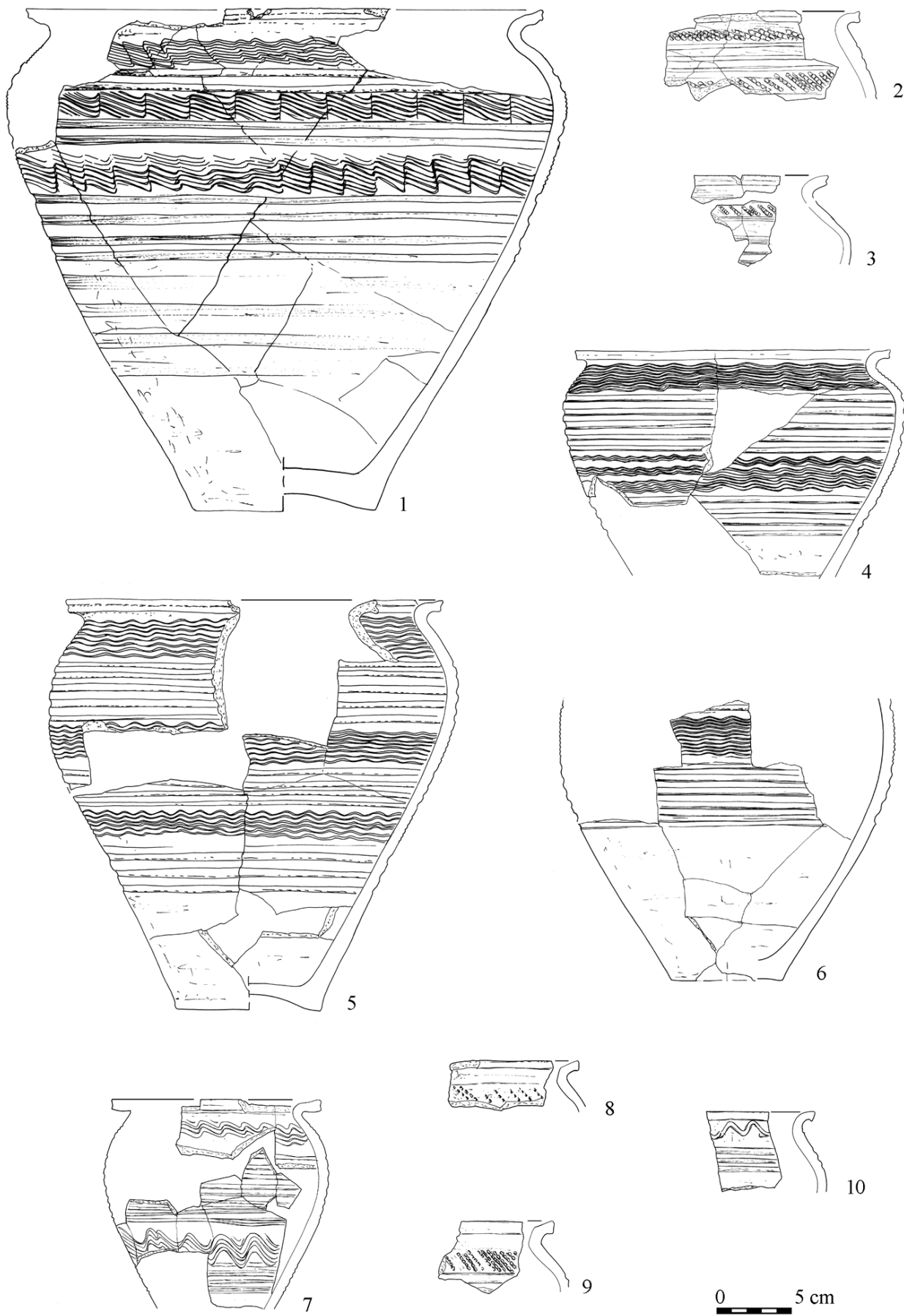

4

10

Fig. 4. Wrocławice, site 1, comm. Milicz. 1, 4-6 - zoned ceramics and forms of Wrocławice-type; 2, 3, 8-10 - fragments of completely wheel-turned vessels; 7 - transitional vessel. 

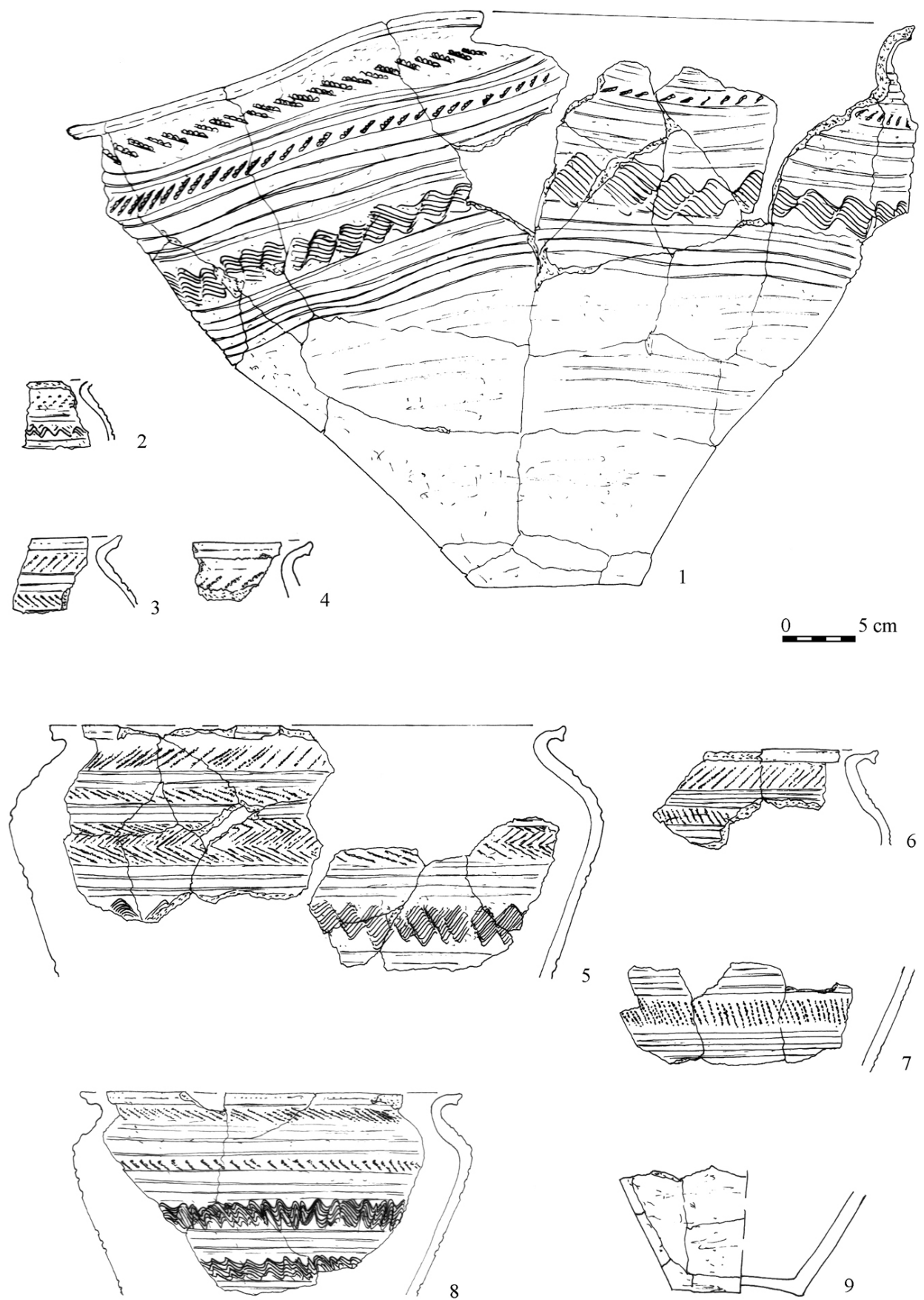

Fig. 5. Daleszyn, site 2, comm. Gostyń. A selection of completely wheel-turned ceramics: 1 - reconstructed wheel-turned vessel, burned out; $2-8$ - zoned vessels; 9 - bottom of the completely wheel-turned vessel. After Hilczerówna 1960. 
Z. Hilczerówna, in her studies of early medieval settlement in the Obra Basin, included zoned ceramics into the so-called group D (fig. 5 - Daleszyn). The chronology of group D was narrowed down to the years 950-1050 AD (Hilczerówna 1967) ${ }^{2}$. Group D, heterogeneous in terms of technology and typology, included vessels made in the technique of partly wheel-turned (pots constituting a form of continuation of the trend already represented in group C), transitional vessels with features typical of newer technology, as well as completely wheel-turned vessels decorated with new forms and composition of ornament (Hilczerówna 1967, 124-125). The last category of ceramics includes zoned vessels that differ in terms of quality, i.e., zoned pots of a worse and better standard. From the point of view of the issues analyzed here, important are the transitional and zoned vessels made in both standards.

From the upper and middle Obra Basin, the term transitional ceramics refers to products partly wheelturned on a potter's wheel at least up to the height of the body band, sometimes also slightly below, with concave bottoms, ornamented in a manner appropriate for zoned ceramics (Hilczerówna 1967, 126-127). The presence of vessels with transitional features is attributed to the phenomenon of mastering a new technique by craftsmen who know more traditional ways of making vessels (Hilczerówna 1967, 126). ${ }^{3}$

The leading technological determinants of zoned ceramics include the presence of concave bottoms, wheel-turned down to the bottom part, finer mineral temper in clay, thin walls, and stronger profiling of the rims (e.g., Hilczerówna 1967, 125-126). These products are distinguished by extensive ornamentation consisting of stripes covering a large part of the body. They present two standards of crafts, reflecting a different degree of quality and use of new technology. Our present knowledge permits us to state that despite the preservation of the clearly traditional ornamentation based on the patterns of motifs made with a comb (horizontal and wavy lines and prints), they were given a new quality by expanding the entire composition layout.

In this approach, the 100-year time interval between 950 and 1050 in the upper and middle Obra appears to be a time of the coexistence of ceramics significantly differentiated in terms of quality. The researcher concluded that the appearance of zoned ceramics in the area should be correlated with influences from the south, from northern Bohemia, and the potters from Silesia may have been "conveyors" of these technical and stylistic innovations (Hilczerówna 1967, 132). In the case of the Obra Basin, the zoned vessels presented clearly variable forms that are mainly visible in the shape of a body: ovoid or barrel-shaped, or biconical (Hilczerówna 1967, 128-130).

The analogies to the assemblage of zoned vessels from the stronghold in Strachów, built south of Wrocław, were of key importance in these considerations (fig. 6, 7; Hotubowicz 1957; Lodowski 1980), as well as in the identification of similar ceramics distinguished by forms and extensive ornamental motifs previously unknown in upper and central Silesia and in the north-eastern part of Lower Silesia, in the Milicz region (Kaźmierczyk 1965, 665-667). The researcher also showed that the oldest zoned vessels of group D stylistically refer to ceramics in north-western Bohemia from the Zabrušany site. This type of pots was distinguished and presented for the first time by Z. Ván̆a (1951). He distinguished a group of biconical vessels decorated in the upper part with combinations of plastic engraved lines and strips of stamps arranged in fish-bone- or branch-like horizontal pattern (Váňa 1961, fig. 3). This researcher pointed out that the characteristic fish-bone motif, appearing on ceramics since the La Tène period, in the early Middle Ages occurs not only in northwest Bohemia, but also in northern Poland, in a somewhat similar variant, albeit

\footnotetext{
2 According to W. Hensel's findings, phase D was dated between 950-1100 AD (Hensel 1950).

${ }^{3}$ We also know examples of transitional vessels from the stronghold in Wrocławice, see fig. 3.
} 

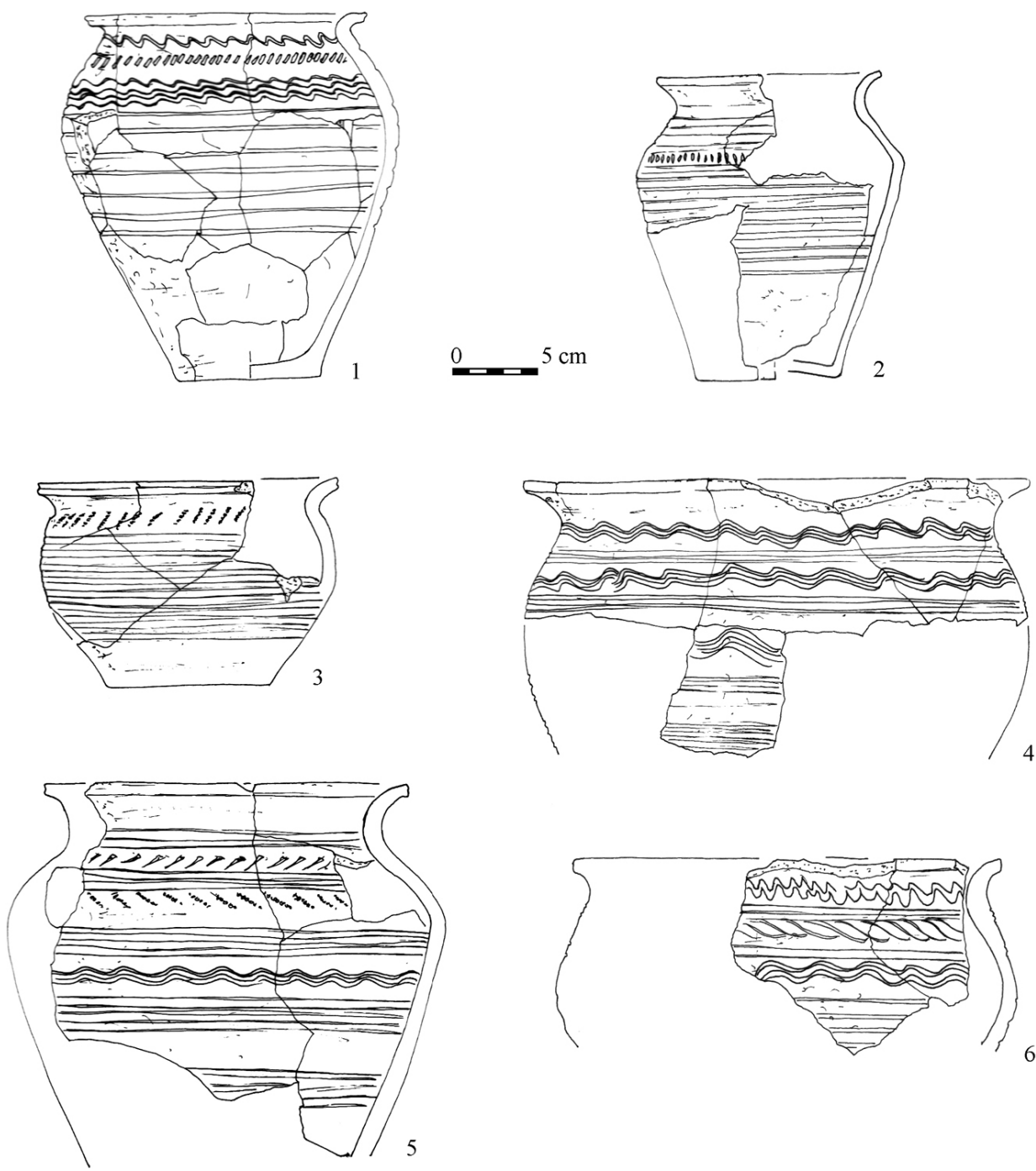

Fig. 6. Strachów, site 2, comm. Sobótka. A selection of ceramics: 1, 4-transitional vessels; 2-3, 5-6-zoned vessels. After Lodowski 1980.

not so commonly (Váňa 1961, 470-471). The imprint motifs that appear on the Zabrušanytype vessels represent a rather seldom used decorative element; they do however appear on early medieval pottery in Bohemia and Moravia.

The chronological horizon of the aforementioned ceramics groups concerns the $8^{\text {th }}$ and $9^{\text {th }}$ centuries in Moravia, while in Bohemia the $9^{\text {th }}$ and $10^{\text {th }}$ centuries, mostly assemblages from sites located in north-western Bohemia, both settlements and cemeteries. According to the current state of research, the above-mentioned vessels show more common features with pots of the Woldegk-type, characteristic mainly for the Mecklenburg-Pomeranian and the middle Elbe regions. 

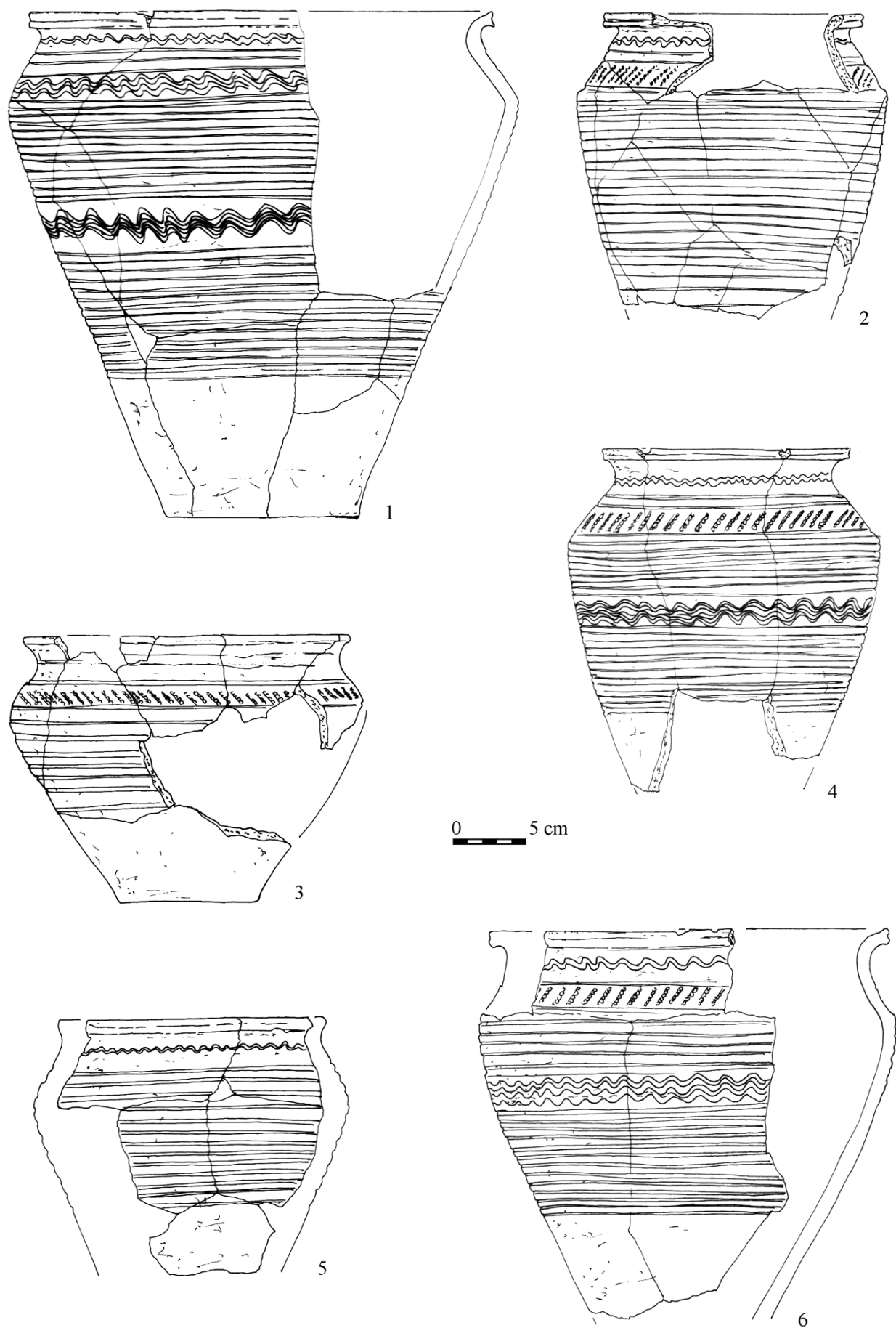

Fig. 7. Strachów, site 2, comm. Sobótka. A selection of completely wheel-turned ceramics: 1-6-zoned vessels. After Lodowski 1980. 
Apart from the above-outlined circle of cultural influences, Z. Hilczerówna, in her work on settlement in the Obra Basin, paid attention to the biconical vessels, which she described as type III (Hilczerówna 1967, 133). The subtype IIIa ${ }^{4}$ in this group is particularly important for our considerations, because such vessels, according to the researcher, show relations with the northern ceramic group, while the ornamentation of these vessels does not differ from other types in group D. It can even be said that type IIIa is characterized by particularly rich ornamentation (Hilczerówna 1967, 133). The researcher did not develop this idea, which would be interesting in the context of the reference to pottery from the Pomerania.

The concept of the southern origin of the zoned ceramics was emphasized in the development of vessels from the stronghold in Kaszowo (northern Lower Silesia). Zoned vessels were found there both in the cultural layer located under the ramparts, connected with the older settlement, and in the layers corresponding to the functioning of the stronghold (fig. 8-9). At that time, groups from Lower Silesia and southern Greater Poland were indicated as analogies to them (Dzieduszycki 1972). The idea of the similarity of the zoned ceramics from Nadobrze to the vessels from Zabrušany was sustained in the work summarizing the research on ceramics in Greater Poland (Hilczer-Kurnatowska - Kara 1994). Once again, reference was made to the study of pottery from Zabrušany, this time by Alexandra Rusó (1991) as part of the analysis of the pottery assemblages from the burial mound in Rochy (Kara 2002, 57).

More recent research carried out by archaeologists from Bohemia and Moravia changed the above interpretations. The vessels richly decorated with horizontal stripes of comb imprints forming a fish-bone pattern in combination with wavy and straight lines have been known i.a., from central Bohemia (Třebovle site, Kolín district; Profantová 2000, fig. 2, 3). An example of the use of extensive ornamentation in the decoration of vessels, composed of stripes of diagonal comb imprints in various configurations, corresponded with surrounding grooves, is the pottery from the hillfort in Libice nad Cidlinou (Princová-Justová 1994). The vessels decorated with such combinations of motifs are typical of the turn of the middle and younger stronghold period and occur in Libice until the mid-10 ${ }^{\text {th }}$ century (Balcárková - Dresler - Macháček 2017, 244, fig. 2).

In the southern part of Czech lands, in the $10^{\text {th }}$ century assemblages from the Nemětice site, the presence of s-shaped vessels and, in some specimens, biconical vessels, distinguished by an extensive decoration placed in the upper, and sometimes in the middle part of the body, composed of stripes of diagonal imprints of a multi-toothed tool, supplemented with plastic bands, sometimes also with a wavy line (Michálek - Lutovský 2000, fig. 116: 7; 123: $1 ; 160: 1 ; 169: 2)$. It is worth noting that the motif of diagonal imprints was also sometimes applied onto the rims (Michálek - Lutovský 2000, fig. 116: 7; 117: 2, 4, 5; 122: 4; 160: 1; 169: 3, 4). Researchers, when considering the uniqueness of this pottery compared to other groups, do take into account, however, that it may be the product of one potter or workshop, of local importance (Michálek - Lutovský 2000, 221).

\footnotetext{
4 Among them were wide-opening vessels (diameter of a rim of $25-40 \mathrm{~cm}$ ) with a high bend. These are forms without a neck, with a strongly vertically bent edge and an edge widening towards the end (Hilczerówna 1967, 128-129). The vessels of the IIIa subtype do not show a genetic relationship with pots from group C, and the closest analogies were those from Gniezno, Bródno Stare, and Piwonice (Hilczerówna 1967, 134).
} 


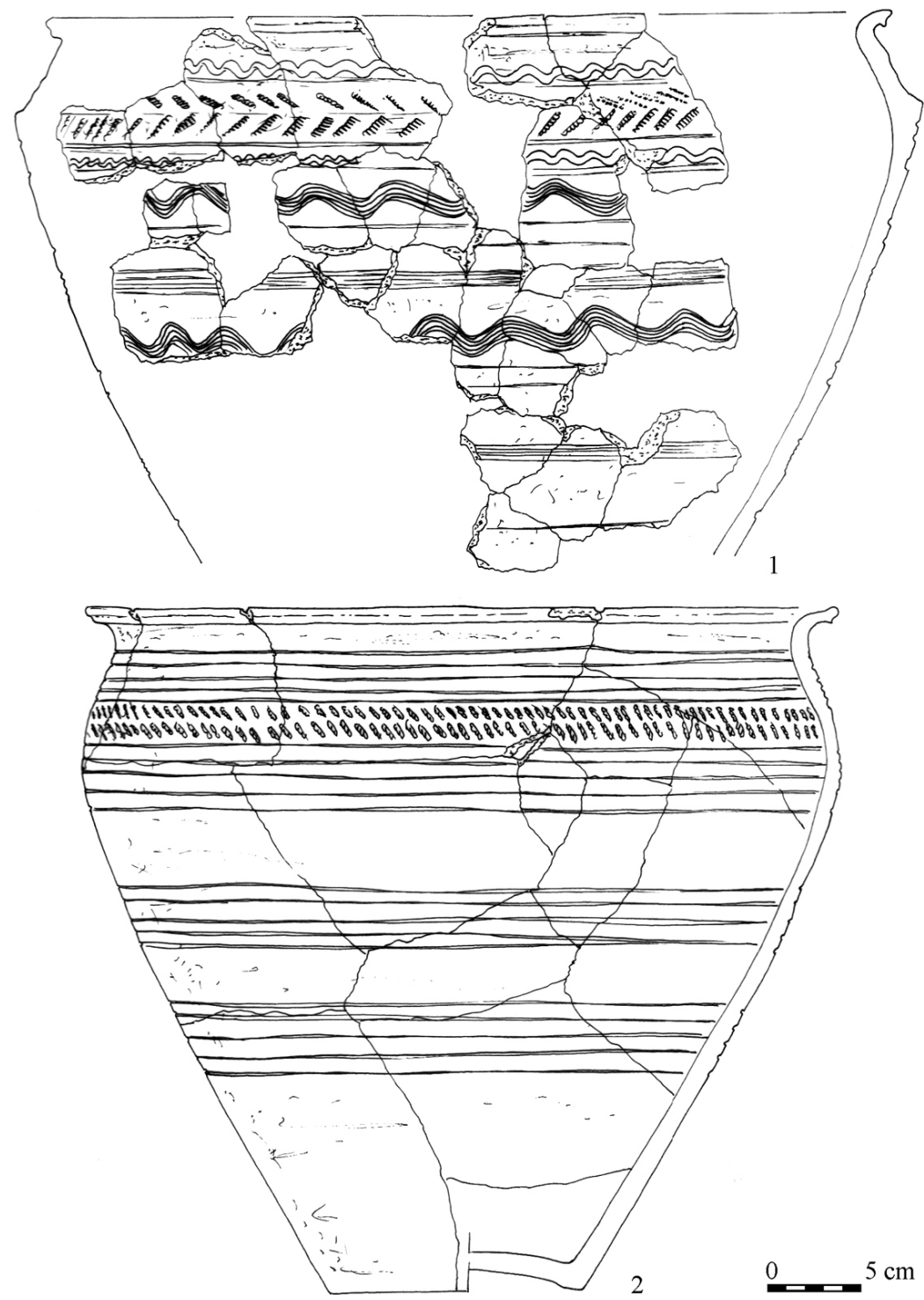

Fig. 8. Kaszowo, site 1, comm. Milicz. A selection of completely wheel-turned ceramics: 1-2 - zoned vessels. After Dzieduszycki 1972.

The vessels decorated with bands of various motifs containing elements of comb imprints (also fish-bone pattern), plastic strips, wavy lines and grooves made with a stylus, ones of various configurations, are present in pottery groups noted at sites in Central Moravia (e.g., Přerov: Procházka 2017, fig. 49: 1, 9, 17; 52: 15; 53: 1, 5, 13; 54: 1, 27; 61: 13). It should be noted that ornamentation with the use of imprints of a multi-tooth tool was often used in Great Moravian ceramics and is visible in the ornamentation of slim s-shaped pots (an example of a group of motifs G, H 1,I 1 i I 2: Macháček 2001, 51, fig. 6). Certain 

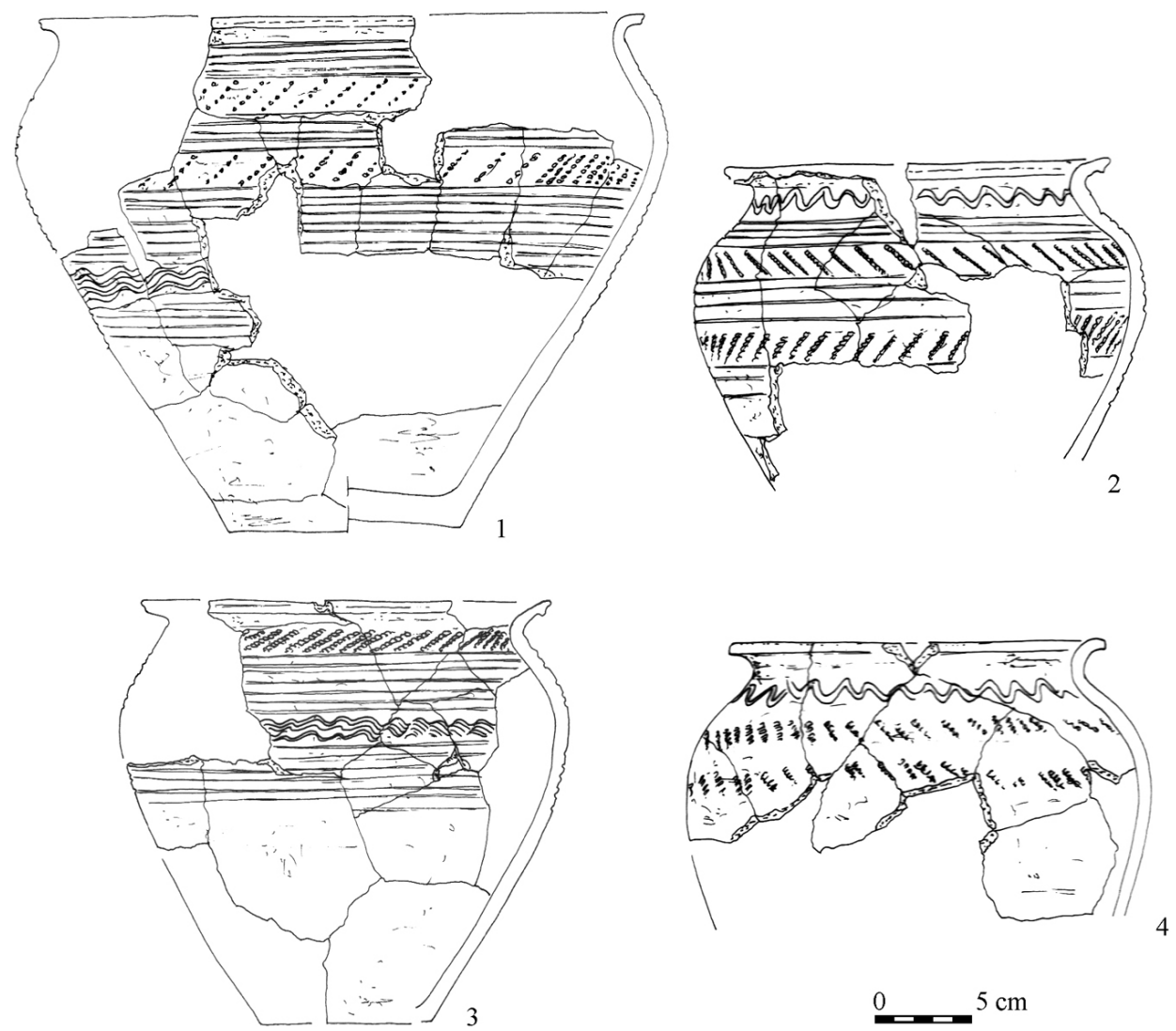

Fig. 9. Kaszowo, site 1, comm. Milicz. A selection of completely wheel-turned ceramics: 1-3-zoned vessels; 4 - transitional vessel. After Dzieduszycki 1972.

references to the ornamentation of the zone ornament can also be found in the style of vessels from the $2^{\text {nd }}$ half of the $9^{\text {th }}$ century when the ornamentation already used a stylus to apply surrounding grooves covering most of the vessel. Several strands of wavy lines, made with a stylus or a multi-toothed tool, were placed between the grooves (e.g., some variants of the Blučina-type; Macháček 2001, fig. 103; 179). It is worth emphasizing that some Great Moravian vessels decorated on almost the entire surface with bands of surrounding grooves and a wavy line made with a stylus are mainly gentle s-shaped forms, but some specimens are distinguished by a body with a clear tendency to a biconical shape (the younger horizon of ceramics is dated from the mid-9 $9^{\text {th }}$ century to ca. 1000 in Mazuch 2013, fig. 24: 4; 25: 4; 27: 2, 5). However, the ornament on the Great Moravian vessels is not as regular as in the case of the completely wheel-turned zoned vessels, decorated with the use of the fast rotation of the potter's wheel.

A unique example of zone-decorated ceramics are vessels found in Opava-Kylešovice (Kouřl - Gryc 2018). The completely reconstructed vessel (Kouřl - Gryc 2018, fig. 25: 1) is distinguished by a form with a high, gently two-conical bend and a concave bottom. The ornament consists of regular bands of surrounding grooves and oblique imprints of 

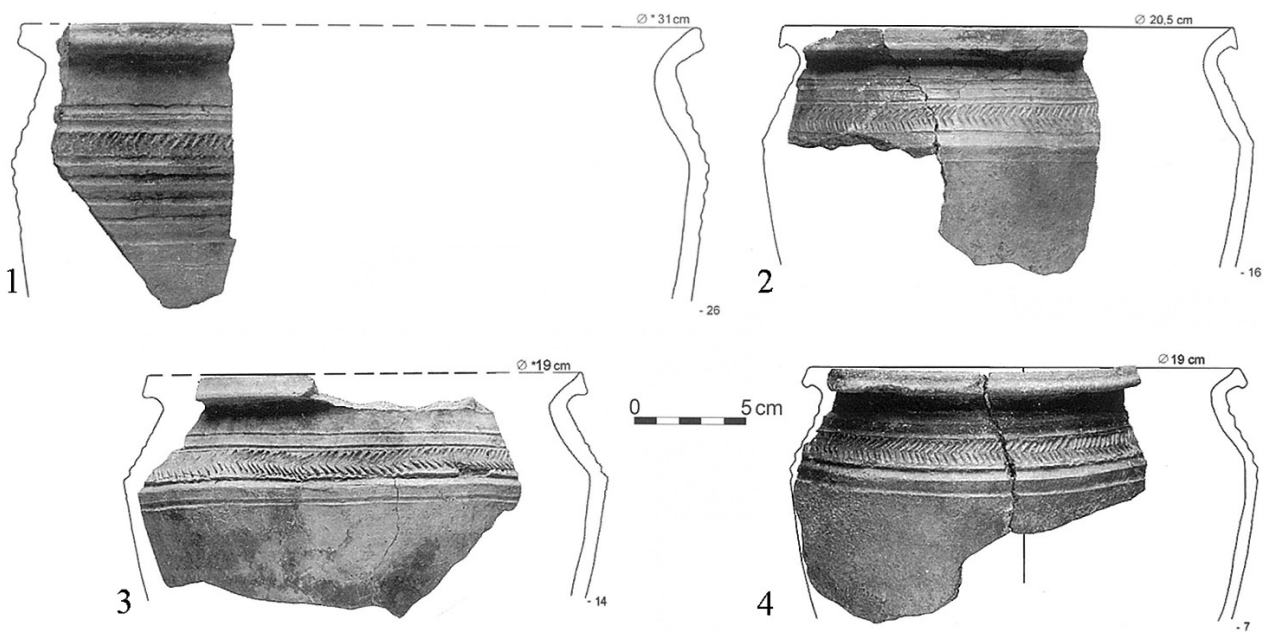

Fig. 10. Zabrušany-type pottery: 1 - Zehren, 2-3 - Meißen, 4 - Dresden-Briesnitz. After Kotková - Lange 2010.

a comb. It was indicated that it is a product with progressive features (general form, concave bottom, separated neck), and it gradually became popular not until the $2^{\text {nd }}$ half of the $10^{\text {th }}$ century. The chronology of this complex is related to the earliest phase of the fortification construction and can be dated to around the middle of the $10^{\text {th }}$ century (Kouril - Gryc 2018 , 201). Analogies of these assemblage to zoned ceramics from Greater Poland and Lower Silesia are clearly visible (Kouril - Gryc 2018, 209-212).

Vessels of the Zabrušany-type, dated to between the end of the $9^{\text {th }}$ century and the mid- $11^{\text {th }}$ century, have recently become an issue of interest to archaeologists from Bohemia (Kotková 2009; Meduna 2015). Contemporary research shows that as many Zabrušany-type vessels as in the north-western Bohemia (mainly the Bílina and Ohře Basins) have been found in Germany, in Saxony, in the south-western Elbe Basin, extending up to its left-bank tributary of the Mulda River. This changes the existing concepts assuming the development and spread of this type of vessel within the framework of pottery developing in the castle district in Zabrušany (Bubeník - Meduna 1994, 186-188). Archaeometry studies of the Zabrušany-type ceramics indicate that these vessels could have been produced in workshops on both sides of the Ore Mountains, both in north-western Czech lands and in Saxony (Kotková - Lange 2010; see fig. 10). The high technological similarity of some specimens found at sites around Meissen may be an argument for the migrations of population groups over both sides of the Ore Mountains, which did not constitute a barrier to contacts between communities (Kotková-Lange 2010,74). When looking for the source of this trend in ceramics, something characteristic of a wider zone than previously thought, various models of "cultural transfer" are currently being considered: through trade, fees (taxes, duties), or population movements, along with political events - i.e., Bohemian military expansion (Meduna 2015).

These new conclusions cause reflection and the necessity to ask whether the Zabrušanytype vessels, which the older literature deemed to be analogies for zoned ceramics, should be related to the interactions with communities living in todays' northwestern Czech Republic, or rather with those living in Saxony. 


\section{"Northern inspirations" in ceramics from the area of southern Greater Poland and the north-eastern part of Lower Silesia}

The change of views on the Zabrušany-type vessels, which were supposed to be an inspiration for the producers of zoned ceramics, and their discovery in ceramic assemblages from Germany, raises the question whether the development of zoned ceramics could have been influenced by inspirations or manufacturers from the area between the Oder and the Elbe. In addition, a kind of "research anxiety" has been brought into this interpretation by the findings concerning the development of Western Slavic ceramics, which indicated that there were two parallel phenomena. The first is the maintenance of supra-regional traditions, constituting a kind of base of patterns, to which we can include the trend of producing pots such as Menkendorf and Tornow - while the second concerns the development of local workshops, something represented e.g., by smooth partly wheel-turned ceramics (Pankiewicz 2012, 90-102; 2020) ${ }^{5}$, the Dalkowo-Obra-type partly wheel-turned pots (Siemianowska 2010) ${ }^{6}$, the Solniki-Lipowiec completely wheel-turned pots (Paternoga et al. $2017)^{7}$. The arguments pointing to clear influences from the Baltic zone (Pomeranian-Veleti) in the ceramics manufactured in Lower Silesia include not only the presence of products of northern provenance (Rzeźnik 1995a, 592-594), but also workshop similarity, in this case, pots with a zoned ornament similar to the supra-regional type Menkendorf (?), as shown by laboratory analyzes carried out in recent years (Stoksik-Paternoga 2009, 39; Kobylińska et al. 2020). As indicated by H. Stoksik and M. Paternoga, on the example of vessels from the settlement in Wszemirów, the basis for the development of zoned ceramics, compared with older findings, prompt reflection about the context of the appearance of the analyzed group of products.

While there are Zabrušany pots in ceramics in Bohemia and Moravia, in Pomerania and Mecklenburg, partly wheel-turned, biconical Menkendorf pots are the main component of ceramic assemblages (fig. 11, 12). The Menkendorf-type vessels were distinguished by E. Schuldt (1956). In Polish literature they were defined as the Szczecin-type, as well as the family of D types; the Menkendorf-type includes hand-made and partly wheel-turned vessels, with a various set of forms, primarily with a marked biconical bend of a body; the ornamentation of Menkendorf pots is very diverse, it covers the upper part of a body. There are also undecorated forms (Losiński 1996, 435-437).

The area with this type of vessel covers an exceptionally wide territory of the Western Slavic region, from the coast of the Baltic Sea in the north, southwards to the Harz Mountains and Upper Lusatia, the Milicz Basin and the Kalisz Upland (the latter two lands are associated with the Barycz River) in the west, and the western border of the Kuyavia Lake-

\footnotetext{
5 According to A. Pankiewicz, it seems that the peak period of the smooth vessels' spread took place in the $2^{\text {nd }}$ half of the $9^{\text {th }}$ and early $10^{\text {th }}$ centuries (Pankiewicz 2012, 95), it is also recorded at sites from the $1^{\text {st }}$ and sometimes even the $2^{\text {nd }}$ half of the $10^{\text {th }}$ century (Pankiewicz 2020, 18).

6 According to the findings of S. Siemianowska the occurrence of Dalkowo-Obra-type vessels has been dated from the $3^{\text {rd }}$ quarter of the $9^{\text {th }}$ century to the mid- $10^{\text {th }}$ century in Greater Poland, at the end of the $10^{\text {th }}$ century and the beginning of the $11^{\text {th }}$ century in Lower Silesia (Siemianowska 2010, 218).

7 The Solniki-Lipowiec ceramics date back to the end of the $10^{\text {th }}$ and the beginning of the $11^{\text {th }}$ century (Paternoga et al, 2017, 99).
} 

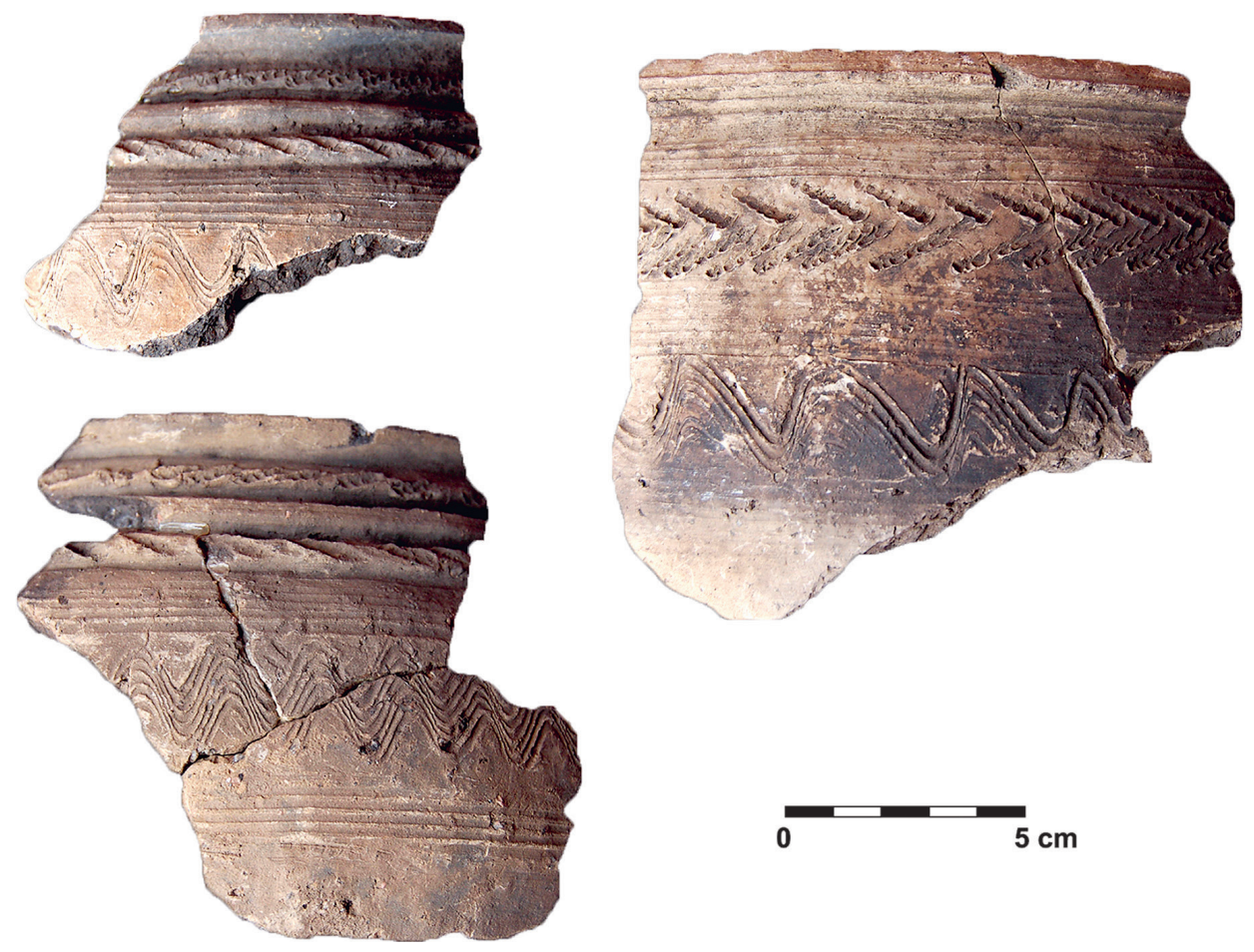

Fig. 11. Examples of Feldberg-type vessels from the settlement in Santok, site 1.

land in the east (Kobylińska et al. 2020, fig. 3: 87). In step with the development of research, archaeologists corrected the range of the Menkendorf-type vessels, which led to its extension and shift towards the south (compare the range in Łosiński 1996, 436, fig. 245, with the map in Kobylinska et al. 2020, fig. 3). The presence of Menkendorf-type ceramics was noted in strongholds in the Obra $\mathrm{Basin}^{8}$, at sites located in the middle zoned of the Odra $^{9}$ and over the Barycz River ${ }^{10}$ and south of the latter river ${ }^{11}$. Archaeometric studies of fragments of these pots, obtained from various sites in the area of their occurrence, showed their very good technical properties, i.e., usefulness as cooking pots (Kobylińska et al. 2020, 110). This feature of Menkendorf vessels as cookware (appropriate technical parameters) could have determined the implementation of the experience gained in their production also for the production of zoned ceramics.

\footnotetext{
${ }^{8}$ In Bruszczewo (Brzostowicz 2002, fig. 14), Bonikowo (Hotowińska 1956, fig. 9: E; 12: A; 17: M; 20: E; 32: A; 44: A) and Daleszyn (Hilczerówna 1960, fig. 35: 1, m, n; fig. III).

${ }^{9}$ Fragments of Menkendorf-type vessels (mainly single pots) can be found in the strongholds in Gostyń, Dobrzejowice, Solniki, Sława and Przedmoście (Biermann et al. 2014, 307).

${ }^{10}$ In the settlement in Czeladź (Lodowski 1972, fig. 73: f), in Osetno (Iwanicka-Pinkosz 2000, 91, fig. 5: 4) and Wszemirów (Paternoga 2003, 167, fig. 8: 1).

11 Apart from the examples from the settlement in Wszemirów, similar vessels were registered in the settlement complex from Łozina (Pankiewicz - Rodak 2019) and from Wrocław Ostrów Tumski (Jaworski et al. 2013, 318).
} 

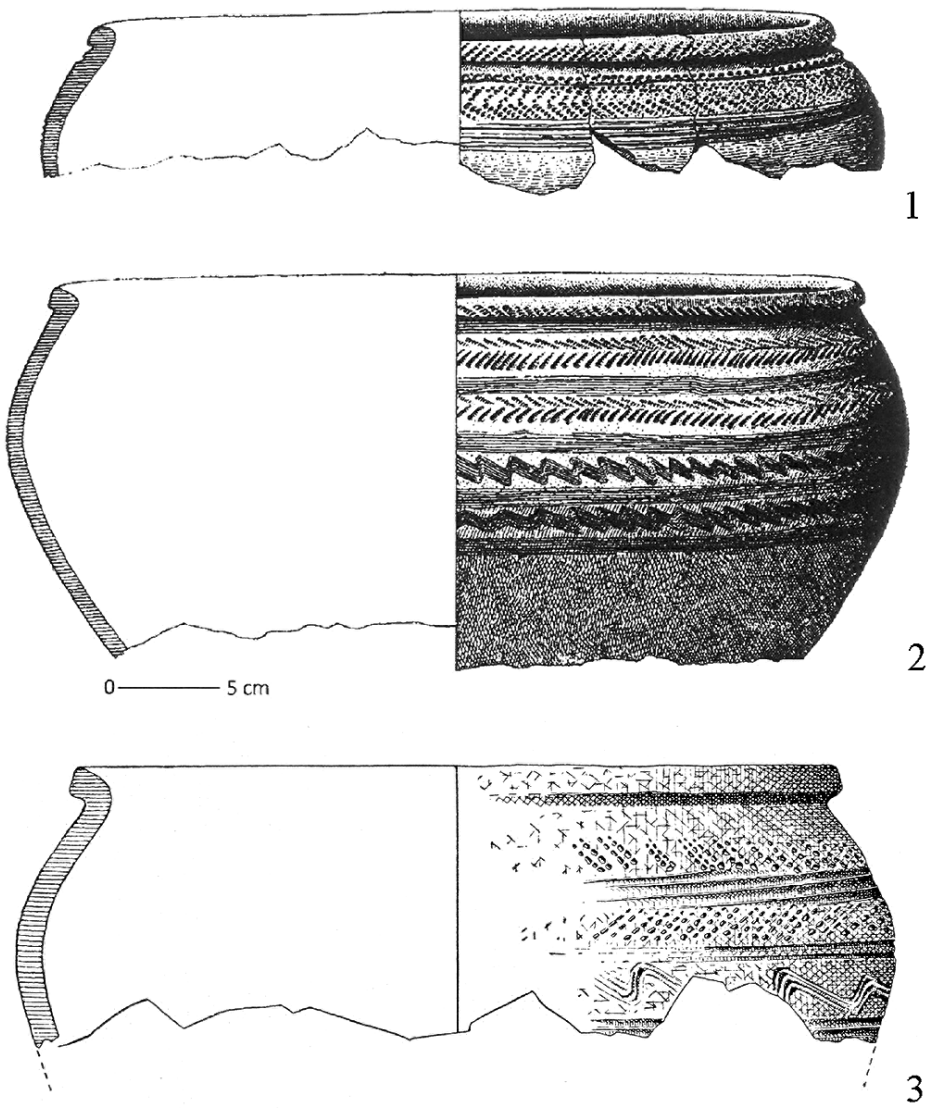

3
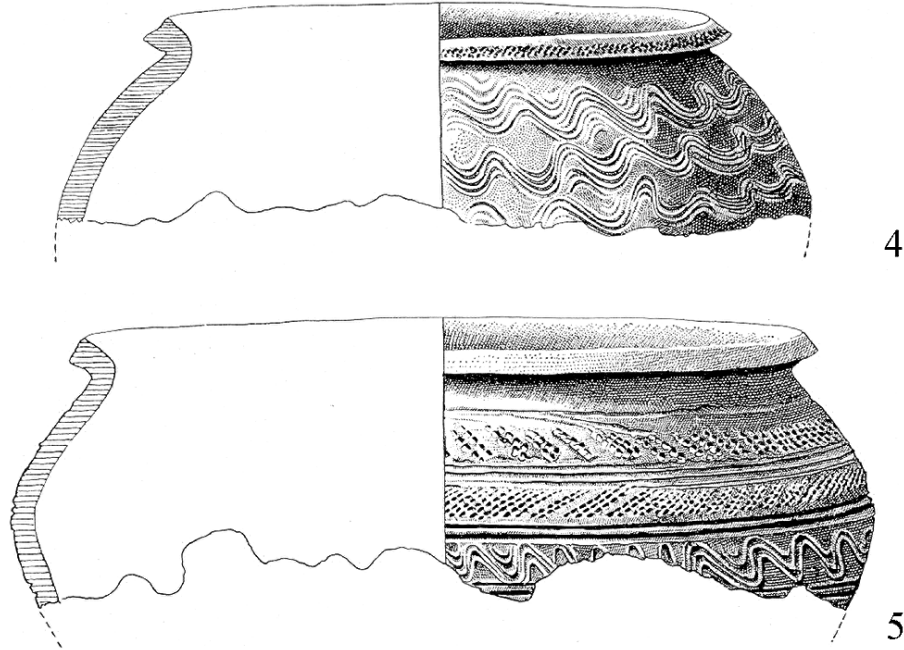

Fig. 12. Feldberg pottery: 1-2 - from the Ravensburg near Neubrandenburg after Schoknecht 1971; 3 - from Rothemühl, Land Ueckermünde after Schuldt 1956; 4 - Feldberg, Land. Neustrelitz and 5 - Rothemühl, Land Ueckermünde after Schuldt 1956. 
In ceramics assemblages of the Menkendorf-type, there are often vessels found referred to as Woldegk (Cnotliwy-Leciejewicz-Łosiński eds. 1983), strongly wheel-turned to the bend of the body and decorated with motifs of plastic bands combined with the imprints of a multi-tooth tool, which distinguishes them from other items (Schuldt 1956). This northern trend of pottery production includes high-standard biconical vessels, similar to those made in the technology of completely wheel-turned. In the production of these pots, there is a tendency to diversify the ornamentation in a multi-lane arrangement and to combine elements of horizontal rollers and grooves characteristic of the Tornow-Klenica cultural zone, as well as motifs of prints and various straight or wavy lines, which have developed more widely in the ornamentation of Menkendorf-type ceramics. The Woldegk-type vessels appear in assemblages not only in the Pomeranian-Mecklenburg zone, but also in Elbe region and Greater Poland, from the $2^{\text {nd }}$ half of the $9^{\text {th }}$ to the $10^{\text {th }}$ century. Importantly, they coexist in assemblages with completely wheel-turned vessels, because their production and use overlap with the stage of introducing items made in this newer technology.

In the ornamentation of vessels, a rich composition of variable stripes of prints and plastic elements had a longer tradition in the Pomeranian-Mecklenburg zone, and in the Baltic zone it occurred already in the $8^{\text {th }}$ and $9^{\text {th }}$ centuries as a characteristic feature of the vessels known as the Feldberg-type (Schuldt 1956) ${ }^{12}$. Certain similarities are visible between the zoned vessels and the Feldberg-type, especially in the sphere of rich, streaked ornamentation covering a large part of the body and the quality of ceramics ${ }^{13}$. Feldberg pots were decorated with a similar idea: regularly arranged horizontal circumferential strands, placed one below the other, also under the rim, up to the area of the widest part of the body. Another similarity concerns the use of a type of multi-toothed tool and the ornamental patterns applied. Surrounding wavy lines and streaks and imprints were applied in various configurations, as well as plastic elements such as ribs and rollers, and decoration of the edges of rims (only in some assemblages). The decorative motifs appeared in a form of an engraved, surrounding straight or wavy line, and the use of a multi-part tool resulted in the formation of very wide bands, covering a large area of the vessel. The stamping technique was also used, most often oblique. Such oblique imprints of the comb formed circumferential strips, and multiplied ones gave the effect of fish-bone.

Similarly to the classic Feldberg pots ${ }^{14}$, also the Kędrzyno-type vessels (according to Eosiński 1972, 52-54), of a slightly lower standard though, have been found in pottery assemblages in the Obra zone ${ }^{15}$.

\footnotetext{
${ }^{12}$ In the divisions developed for materials from the territory of Poland, such vessels refer typologically to specimens with a strong pattern, included in the family of $\mathrm{C}$ types distinguished for Pomeranian ceramics (Cnotliwy Leciejewicz - Łosiński eds. 1983, 203-205), and within its type b - called Bardy (Losiński 1972, 43-44, fig. 7, 19: e, f, g; 16: a-i; the counterpart is the Feldberg-type 2-3 series, according to Schuldt 1956, fig. 21; 22).

13 Sebastian Messal mentioned the occurrence of transitional and early late Slavic vessels in ceramic assemblage from the stronghold in Glienke in which the influence of Feldberg ceramics is visible; inspirations concern the method of performed and finishing (Messal 2015, 83).

14 The characteristic of this type was presented by E. Schuldt (1956, 17-22), who distinguished within it 3 varieties (Reihen), which resulted from the large internal differentiation of this type of vessel (various quality of workmanship and ornamentation).

15 Including Bonikowo (Hilczerówna 1960, Hołowińska 1956) and Bruszczewo (Brzostowicz 2002, fig. 10). These vessels can be connected with the horizon dating between the end of the $9^{\text {th }}$ and the $1^{\text {st }}$ half of the $10^{\text {th }}$ centuries.
} 
While searching for "northern inspirations" and the directions of influence on zoned ceramics characteristic for the area of southern Greater Poland and northern Lower Silesia, apart from ornamentation, attention is drawn to the form of the vessel - more precisely, to the biconical appearance of the pot. This method of shaping the body, with a clearly emphasized bend, also applies to completely wheel-turned zoned vessels ${ }^{16}$. The form of the biconical body is significant for the pottery trend related to the Menkendorf-type in the Pomeranian, Mecklenburg, and Elbe areas, together with the Tornow-Klenica zone, in contrast to the slightly profiled vessels associated with the traditions of the southern cultural circle. In the case of Polish lands, it can be stated that the "morphological tendency" visible in the $8^{\text {th }}-11^{\text {th }}$ centuries in the biconical form of the vessels is interregional and covers the area from Pomerania, across Greater Poland, Kuyavia and Chełmno lands (Knorr 1937, 124; Neustupný 1948, 427-428; Hensel 1971, 440). The presence of biconical forms of pots without a separate neck, representing the oldest horizon of the zoned ceramics, in this context would rather be the result of relations with areas where such a form is most common.

Summarizing this part of the discussion, the most important remarks concern the novelty as compared to the former views, which had pointed to southern influences from the Moravia-Bohemia zone as the most important source of inspiration and changes in the production of zoned vessels in southern Greater Poland and the north-eastern part of Lower Silesia. Comparative studies undertaken in recent years by researchers from the Wrocław centre have revealed the presence of Menkendorf-type vessels in ceramic assemblages in Lower Silesia (Rzeźnik 1995b; Siemianowska 2017). The physicochemical analyses of zoned ceramics from the site in Wszemirów (in the terminology of Stoksik and Paternoga segment-zoned ceramics), carried out so far, although to a small extent, revealed its similarity in terms of technology, with the Menkendorf-type pots and the north-western pottery traditions (Stoksik-Paternoga 2009, 34-36, particularly 39). Findings of Menkendorf-type vessels in northern Lower Silesia mark, in the light of more recent research, the specific southern boundaries of the wide area of occurrence of this vessel type in ceramic assemblages. A similar phenomenon applies to cups with empty legs, the southern range of which is determined by the line of the Barycz River (Kolenda 2011, 51). Our considerations have also proved the presence of certain common features of zoned and Feldberg ceramics in terms of technological quality and the idea behind the decoration. We consider adopting the general idea, and not duplicating detailed ornamental patterns. For example, the zone ceramics were not decorated on the edges of the rims, which is the case with some Feldberg-type vessels. Chronologically, Feldberg-type vessels are much ahead of assemblages with zoned pottery, as the period of their occurrence is connected mainly with the $8^{\text {th }}$ and $9^{\text {th }}$ centuries, although it might have endured for longer (Losinski 2008, 108; Biermann 2019, $25)^{17}$. Reference also seems possible to the aforementioned ceramics groups from Bohe-

\footnotetext{
16 The bend of the body formed in this way is characteristic i.a., for assemblages from Strachów (Lodowski 1980, fig. 5), Daleszyn (Hilczerówna 1960, fig. 31: d, 32, 36: a;), Golina (Teske 2005, fig. 2), Poniec (Zamelska 1995, fig. 12: 4.5.7; 13: 4.5), Czerchów (Motylewska 2010-2012, fig. XI).

17 Recent studies carried out on the stronghold in Glienke revealed a significant percentage share of the Feldbergtype ceramics in the assemblage. Sebastian Messal initially considered that Feldberg pottery was not replaced
} 
mia and Moravia, richly decorated with wavy and horizontal lines with a high frequency of comb imprints, including the fish-bone-like pattern, as they also coincide with the period of the $8^{\text {th }}$ and $9^{\text {th }}$ centuries. Quite probably this is a phenomenon of a wider range within the Western Slavic region, related to the general tendency to decorate more of the surface of vessels with ornaments and the introduction of multi-toothed tool prints in various configurations into the ornamentation.

In the context of the above considerations, the area of frequent occurrence of zoned ceramics (southern Greater Poland with the basin of the Upper and Middle Obra, and the northern part of Lower Silesia together with the eastern part of the Barycz Valley), would be located at the junction of territories with differing traditions of ceramic production, i.e., within which various styles and trends may interfuse and combine. The intensification of relations at this area had taken place already in the period preceding the emergence of the trend toward zoned ceramics, and the direct basis of the process would have been the Tornow patterns ${ }^{18}$ (including Tornow $\mathrm{C}$ variety, the equivalent of Menkendorf in the Pomeranian-Veleti zone). Therefore, these communities were not influenced by only one of the cultural zones - Bohemia or Moravia, as they existed within the range of various impacts, including those from Pomerania and the mid-Elbe, the intensification of which can be dated to the turn of the $10^{\text {th }}$ century.

Two new elements in the pottery manufacturing combine in the zoned vessels: stylistics, i.e., an extensive, striped ornament, and the innovative technology of a completely wheelturned on a potter's wheel. Vessels made in that new technology appeared in various parts of the Slavic region at a similar time (turn of the $10^{\text {th }}$ century; Dworaczyk 2008, 277, in the amount of $3 \%$ ) having their local features: Solniki-Lipowiec-type, northwestern Lower Silesia, or Vipperow-type in Pomerania. Despite the fact that in northern and central Greater Poland, the oldest groups of completely wheel-turned ceramics appear in a similar time, this phenomenon has a completely different background, related to the native tradition. According to Michał Kara, the production of that kind of vessels was undertaken in central and northern Greater Poland with the participation of foreign, specialized potters, coming from the areas of upper and middle Obra, Western Pomerania, or possibly the northern Elbe region (Kara 2009, 255). In the context of such an approach, it would be a technological and stylistic pattern unknown to the older ceramic tradition in this area. More recent findings therefore indicate a directional change of the influences, one that in older literature had been associated with the southern cultural zone, treated as a source of innovation in the technology and style of vessels (Hilczerówna 1967).

by Menkendorf-type pottery at the end of the $9^{\text {th }}$ century, but it also appeared in the $1^{\text {st }}$ half of the $10^{\text {th }}$ century (Messal 2011, 348). However, the revision of these conclusions in another publication eliminates the middle of the $10^{\text {th }}$ century, although it leaves the possibility of survival of these vessels at the beginning of that century (Messal 2015). Felix Biermann notes that the production of Feldberg ceramics showed a strong dependence on regional economic conditions and was subject to significant differences in the time-space context (Biermann $2019,25)$. This is a very important remark, as it indicates that there is no single applicable caesura marking the end of the use of Felberg-type vessels in the zone of its occurrence.

18 A similar line of development was also observed in the formation of Dalkowo-Obra-type of vessels (Siemianowska 2010, 218). 


\section{Zoned ceramics - redefinition}

The results of macroscopic analysis of vessel assemblages obtained from the sites located near the Barycz River became the basis for defining the term "zoned ceramics". We consider such vessels to be made of various-grain-tempered fabric, completely wheel-turned, with ornament covering an entire vessel, or almost the whole surface, excluding a fragment of the bottom zone. The certain differences in the quality of workmanship and technical parameters have become the criterion for recognition of two standards of workmanship: less and more technologically advanced. Despite the qualitative variability (a different degree of use of the potter's wheel), in both standards pots without a separate neck, with an s-shaped or biconical body, and storage vessels were produced. The ornament on the surface consisted of multi-motif strands covering a large part of the vessel. The common feature of ornamental compositions (in the case of vessels obtained from sites located in southern Greater Poland and the north-eastern part of Lower Silesia) was that of repeatedly occurring horizontal bands of grooves. They separated strands of wavy lines, engraved, stabbed, or imprinted motifs, and unornamented strands (empty strands, see fig. 4; 5; 8; 9). Occasionally, ornamental motifs were also stamped. Sometimes such compositions were supplemented with a plastic rib (fig. 8: 1, they were also used on transitional vessels, fig. 3: 1). A multi-motif ornament subordinated to the rotation of a wheel was applied with a multi-part tool (up to 10 teeth), although a single-cut tool (stylus) was also used. The clear standardization of zoned ceramics at the level of form and the general pattern of ornamentation (repeatability of the motif of surrounding grooves) makes such vessels stand out from others in the assemblages. However, it should be noted that these items vary in details, primarily in terms of the method of applying individual motifs, and the composition of an entire ornament or the general bend line of a body (ovoid or slightly biconical). The extensive, multi-motif ornamentation, composed of various stripes arranged horizontally, is an important feature of zoned pottery. In the analyzed area, extensive, multi-motif ornamentation not only distinguishes zoned vessels from pots made in the older tradition (partly wheel-turned), but also differentiates the zoned wares themselves. The analysis conducted leads to the reflection that the existence of differences in style (the composition of the ornament) as well as in standards of workmanship, and relations between them, is important not only within zoned ceramics but also as compared with transitional ceramics from the area between the Obra and Barycz Rivers. These findings will allow us to define the specificity of zoned vessels from particular centres and to observe features related to the older, native substrate and those that are of a new quality.

The scheme of periodization of ceramics developed by W. Hensel and then made more precise by Z. Hilczer-Kurnatowska, arranged the cultural phenomena occurring in the area between the Obra and Barycz Rivers in the timeline. The chronology of the strongholds in southern Greater Poland was based (and still is, to a large extent) on the phases established by these archaeologists. According to older views, small town-village complexes dating from phase D (950-1050), where in cultural layers partly wheel-turned, transitional and zoned vessels were found, are associated with the functioning of the Piast state (Teske 2000; Kurnatowska 2009, 86). In recent years, with the growing availability of the dendrochronological and radiocarbon dating methods, it has become possible to determine the time of construction and functioning of the strongholds more precisely, and this has 
changed the previous, standardized (static) image of the settlement. The strongholds where the zoned vessels were registered began to rise at the end of the $9^{\text {th }}$ century. They were part of the landscape shaped by local communities (a small stronghold is the element of a landscape formed by pre-state communities). More numerous groups of zoned ceramics were identified from some strongholds dated to phase D and subjected to chronological correction. The correlation of dates and the percentage share of zoned vessels indicates the site Daleszyn as a centre with an $8 \%$ frequency of zoned vessels already at the beginning of the $10^{\text {th }}$ century. The vessels were obtained from the $2^{\text {nd }}$ phase of the stronghold, dated to the $1^{\text {st }}$ decade of the $10^{\text {th }}$ century (after 899 , late tribe horizon, Kara 2006, 221). Currently, this is the only example of an assemblage with zoned pottery along the Obra River, dated dendrochronologically, with such an early chronology. Within the next level of occupation distinguished at the site, dated to the $2^{\text {nd }}$ half of the $10^{\text {th }}$ century, the frequency of zoned vessels increases to $45 \%$ (Kara 2006, 221). From the cultural layers of the stronghold in Dusina, also built upon the Obra River, $73 \%$ of the completely wheelturned ceramics were obtained (traditional dating - phase D, still in Hensel's extended chronology 950-1050, Kihl-Byczko 1965). In the case of the Golina stronghold, whose expansion took place after 946 , there may be observed a clear share of zoned vessels. The author of the study did not specify the percentage share of these vessels in the total number, however, it can be concluded from the description and the attached figures that the presence of zoned vessels is significant at the site (Teske 2005). The other sites, with absolute dates, from which the collections of zoned vessels were obtained, are strongholds built along the Barycz River. The stronghold in Kaszowo was erected after the year 949 (Kara et al. 2006), and the frequency of zoned vessels, determined on the basis of analysis of ceramics (vessels from the stronghold and settlements) is $68 \%$ (Dzieduszycki 1972, 393). At the next site, in Wrocławice, built along the Czarna Woda (the right-bank tributary of the Barycz River), there was a $55 \%$ share of zoned ceramics in the assemblage (Kolenda-Zamelska-Monczak 2020). Dendrochronological analyzes of wood collected from the southern part of the ramparts showed that the object was built from wood cut in the time range from the year 925 to after 996 (Kara - Krapiec - Teske 2006, 129). The dates of burnt wood from the trench excavated in 2014 in the north-eastern part of the ramparts indicate the building of the gate after the year 1080 (Kiarszys - Kolenda 2017, 106). The presence of zoned ceramics was proved at the open settlement of Milicz (material known from autopsy), but already at the initial stage of the analysis we may determine its frequency also as considerable ${ }^{19}$. At the other sites, there is no data on the percentage of zoned pottery. It is only possible to distinguish sites where such vessels occur, without any information about their frequency in assemblages, based on the study of literature. The difficulty is also related to the fragmentary preservation of the pots, which limits the correct recognition of the zoned ornament on the basis of small pieces. Observations regarding the pattern of motifs may be made only on well-preserved larger parts of the vessels or whole specimens. This makes it impossible to observe the chronology and range of occurrence of this type of vessel. This problem concerns the area between the Obra and Barycz Rivers, as well as other sites from Greater Poland and Lower Silesia.

\footnotetext{
19 A detailed analysis of the ceramics from the settlement in Milicz is currently being carried out, the aim of which is to comprehensively develop the material obtained during the research in the years 1960-1962.
} 
Apart from the area between the Obra and Barycz Rivers, the zoned ceramics can also be found in other parts of Greater Poland and in the neighbouring areas. Their number in assemblages varies and they constitute one of the components in the structure of the collections, apart from partly wheel-turned vessels. They are commonly associated with the oldest horizon of vessels made in the new technology. In Giecz, located in the central part of Greater Poland, the presence of zoned vessels was recorded in the $2^{\text {nd }}$ stratigraphic level, exposed at the relics of the palatium, dated to the $2^{\text {nd }}$ and $3^{\text {rd }}$ quarter of the $10^{\text {th }}$ century. This is an assemblage containing the first fragments of completely wheel-turned pottery, including "specimens corresponding to group D according to Hilczerówna" with a zoned ornament (Krysztofiak 2005, 300). In addition to them, the presence of partly wheel-turned ceramics and the transitional ones, as well as Vipperow pots have been observed. At a younger level, zoned vessels were no longer present (Krysztofiak 2005, 301). On the lake island Ostrów Lednicki (Lednica Holm), such vessels ${ }^{20}$ were found in the stratification of the second level, dated to the mid-10 ${ }^{\text {th }}$ century (Eastowiecki 1989, 23). The presence of the zoned ceramics was also recorded in other assemblages from sites within central Greater Poland, but they did not constitute a dominant component in the structure of the entire pottery group ${ }^{21}$.

The zoned vessels are also largely related to vessels from the stronghold in Czerchów near Łęczyca (Motylewska 2010-2012), Kruszwica in Kuyavia (Dzieduszycki 1982, fig. XXV and XXVII-3) and Chełmno lands (Chudziak 1991). The tendency to decorate vessels with extensive ornamental patterns appears to be a phenomenon of a wider range, especially in the period between the $2^{\text {nd }}$ half of the $10^{\text {th }}$ and the $1^{\text {st }}$ half of the $11^{\text {th }}$ centuries. The ceramics groups in these areas may be inspired by zoned ceramics from the south of Greater Poland and northern Lower Silesia, but importantly, these products show some native formal and stylistic differences. In the case of Kruszwica and Czerchów, in the multi-lane pattern, we observe an intensive occurrence of the motifs of a wavy line made with a stylus, with the presence of less numerous oblique impressions and a wave made with a comb (Dzieduszycki 1982, fig. IX - type VII; Motylewska 2010-2012, fig. XI). In the Drwęca Basin, the compositions mainly used a comb to make oblique prints and a wavy line, and the strands do not include the lower part of the body (Chudziak 1991, fig. 13). In this area, richly ornamented vessels appear in the form of a biconical and a spherical shape, often with a plastic band on the body, which is also a clear analogy to vessels from southern Greater Poland or Kuyavia (Dzieduszycki 1982, 40, fig. XXV; Chudziak 1991, 92-94). The bands of dense, surrounding grooves under the rim can be assumed to be a local element (this can be seen as a similarity to the Drohiczyn-type; Chudziak 1991, 101). Zoned vessels have also been recorded in centres located on the northern edge of Greater Poland, e.g., in Santok, but in the entire assemblage they constitute only single items (type XIX in the VI settlement level, $1.5 \%$; Dymaczewska 1970, fig. 26-27).

The use of the zoned vessels was limited in time. The extensive ornamentation had been gradually limited in favour of single- or double-motif ornamentation (vessels deco-

\footnotetext{
20 Zoned vessels are pots in the VI and IX type family, which the author mentions as the only completely wheelturned pots in the group. Their share is $60 \%$ (Lastowiecki 1989, 23, fig. 3).

21 Including those from Poznań-Ostrów Tumski (Niesiołowska-Perzyńska, Żak 1960, 76, fig. 10) and Bnin (Pałubicka 1975, fig. XXII: 11, 12, 15, 16).
} 
rated only with surrounding grooves or grooves and a single motif). Diagonal imprints made with a comb, especially the characteristic arrangement in the fish-bone pattern, did not become a permanent element of ornamentation used in the decoration of other completely wheel-turned vessels. Also, the use of a multi-toothed tool for surface decoration, most popular in traditional manufacturing, continued only to a very limited extent. It lost popularity in favour of a single-tooth tool. The process of gradual disappearance of zoned vessels in the assemblages coincides with the discontinuation of the production of forms typical for local communities (Dalkowo-Obra or Solniki-Lipowiec vessels).

\section{Why did small local communities start producing zoned vessels in the area between the Obra and Barycz Rivers?}

The cultural context of changes occurring within local communities (face-to-face-society) comprise the internal relations within these groups and the realities of the neighbouring areas: northern, western, and southern Europe from the last quarter of the $9^{\text {th }}$ century. The weakness of East Francia, the rise of Great Moravia, followed by their fall at the beginning of the $10^{\text {th }}$ century with the Magyars invasion of Pannonia, these are only the most important events that catalyzed the internal and external interactions between the communities living in the Western Slavic region. The collapse of the Great Moravian state not only changed the political and cultural reality in this region, but also gave rise to the new Przemyslid and Arpad states. The change of the previous governance south of the Sudetes and west of the Carpathians could also have had a very "practical" dimension. It could have involved the relocation of some part of the Great Moravian communities in search of a new area suitable for settlement. These groups could also have include potters, and such a phenomenon could have developed especially in the first quarter of the $10^{\text {th }}$ century, that is, the period of the collapse and disintegration of the Great Moravian state (Pankiewicz 2020, 418). During this period, changes in the southern (Moravia and Bohemia) and western (Elbe) zones were intertwined with the activity of the Vikings raiders and traders, moving in search of various types of goods. The establishment of the Baltic economic zone (Łosiński 2008) led to a transformation of the coastal landscape, where emporia and trading places were the most active places. Although the archaeological literature emphasizes the activation of Vikings mainly in the coastal area and the Baltic islands, there are suppositions that they also penetrated lands further away from this zone, including the Piast state. The centre in Santok (Zamelska-Monczak ed. 2019) can be cited here, which was already in the $9^{\text {th }}$ century a gateway that opened access to the interior (Greater Poland) through the Warta, Noteć and Obra Rivers. The Odra River, which made it possible to reach Santok, was also communication and commercial artery connecting the communities living in the Baltic zone with those from Silesia, and through the Barycz River also with those existing in the headwaters of this river.

Changes in the southern part of the Western Slavic region had an impact on the shaping of the communities living in the area between the Obra and Barycz Rivers. Their existence in the new political and economic system made it necessary to redefine internal relations between particular communities and their relations with the outside world. Interactions between neighbouring, local communities were shaped, as well as those living at greater distances (Bohemia, Moravia, Elbe region, Scandinavia). Local communities could have 
responded to such a transmission of innovation in various ways: by accepting or refusing the constituted reality. In our opinion, regardless of the adopted attitude, the communities functioning in the traditional model had to self-define in the context of the socio-cultural reality undergoing intense changes and to develop relations with the newly created structures. It may be hypothesized that the result of these changes could have been the creation of stylistically diversified zoned ceramics. In such a research proposal, zoned vessels become the basis for analysis of the changes occurring in traditional ceramics as caused by social transformations within the local communities in which it had been developed. Adopting or developing new technology ca. 900 AD by local communities, combined with a new stylistic model, could have been a way of manifesting one's local identity in the new reality. Local communities started to produce zoned ceramics because in relations between particular communities with different cultural patterns it was a form of communication with identity connotations.

Was the production of new quality pots due to external inspirations or direct contacts with potters using more advanced technology, or was it due to changes in local production?

Considering the ceramics in the wider area, as outlined above, it should be stated that it is not a direct consequence of inspirations arriving only from the southern zone. Ceramic standards widespread in Pomerania may have contributed to its production. The northern patterns in pottery were accepted in Greater Poland, also in the Obra zone, already at the level of partly wheel-turned pottery of the Menkendorf-type, and the presence of these vessels is not related to the Piasts' state. It should be considered whether the communities living in the area where the state was formed (the lands of Gniezno) did not draw innovative models from the north, from the cultural zone that was well known to them, in which not only Menkendorf-type pots were produced, but also other richly decorated types of pots (e.g., Feldberg or Woldegk). This does not prejudge the necessity to adopt patterns from there, but it does not exclude them either. Paweł Rzeźnik rightly noted that contacts led to becoming acquainted with foreign features that could be adopted as ready-made patterns, assimilated in a more or less transformed form, or were an impulse to create one's own solutions (Rzeźnik 1997, 127).

From the perspective of our research carried out at sites in the upper part of the Barycz River (Wrocławice-type vessels), zoned ceramics is an element of local ceramic production. Accepting W. Hensel's views on not transferring the conclusions developed for one area to another, we suggest considering zoned pottery from individual sites in the context of their occurrence. One kind of information is carried by zoned vessels in the context of partly wheel-turned and transitional vessels (the Barycz or Obra Rivers), and another in assemblages from sites located in the centre of the Piasts' state. This context is important and should be considered whenever analyzing and determining the regularities specific to a particular centre.

Was the acceptance and implementation of the new technology combined with a different style occurring in the entire analyzed area in the same way and at a similar time? or maybe gradually, at different periods, as a result of the independent contacts of individual communities?

The zoned vessels on the level of general physicality are apparently the same, but the details are different. The analysis of zoned ceramics in the north-eastern part of Lower Silesia and southern Greater Poland has shown that it is a stylistically heterogeneous trend, which may reflect the contribution of local manufacturers in its shaping. An example is 
a separated form of Wrocławice-type (Kolenda-Zamelska-Monczak 2020). We could rather discuss general tendencies and a clear standard as being visible in a wider area, but with local variants concerning the shape of the body (with a preserved form of a pot without a neck), and the selection and order of motifs in strands (made with a single or multi-part tool). These slight differences determine the local features of the ceramics, characteristic for a specific site/assemblage. One might venture that there are no identical assemblages of vessels within zoned ceramics, and each of them is specific for a given centre, dedicated to a particular group of users.

\section{Conclusions, or the devil is in the micro-details}

1. Zoned vessels were obtained from the cultural layers of strongholds, settlements, cemeteries and in one case also a deposit (a treasure hoard). Despite the fact that these vessels have been noticed in the greatest number at sites between the upper Barycz River and the upper and middle Obra River, they are also known from the sites located in the centre of the former Piast state, in Kuyavia and the Chełmno lands, but in different numbers. There are both ceramic assemblages in which the frequency of zoned vessels oscillates around $50 \%$, and those in which it is much smaller, around a few percent. Therefore, we can indicate sites where zoned ceramics dominate and those where they are only additional ones (fig. 2).

2. Zoned vessels were produced via the new technology of wheel-turning and decorated with elaborated compositions. Two different technological standards have been recognized herein. The transitional vessels have been collected at several sites, and they might have resulted from the implementation of a new technology into the local ceramic manufacturing. At this point we can agree with the statement by P. Rzeźnik, who suggests accepting some of the more advanced potters' [techniques] may reflect either closer direct contacts between producers and the mutual sharing of experience, or indicate a similar degree of a general technological level, allowing an effect to be achieved similar to the original by means of independent experience (Rzeźnik 1997, 127), as exemplified by the pots of Wrocławice-type (fig. 4).

3. There are no clear arguments indicating that the appearance of zoned ceramics was inspired by any impulses arriving into southern Greater Poland from the centre of the Piast state. Firstly, in state-owned centres they do not constitute a dominant type of vessels; secondly, in the south-eastern part of Greater Poland and in the north-eastern part of Lower Silesia the mechanism known from other areas of Polish lands, and reflected in the construction of state strongholds and the production of early-Polish ceramics, standardized in terms of stylistic and technology, has not been observed (Buko 1999, 199-200; Trzeciecki 2009, 217-219).

4. The conducted recognition also shows that the zoned vessels represent a stage of wider changes of ceramics production occurring in the $10^{\text {th }}$ century and leading to the formation of local types of vessels produced by local communities. This applies to both partly wheel-turned pottery, i.e., Dalkowo-Obra ceramics, and completely wheel-turned pottery, i.e., the Solniki-Lipowiec-type, associated with communities inhabiting the area identified with the Dziadoszan tribe. The related horizon of the strongholds disappears at the beginning of the $11^{\text {th }}$ century. 
Changes in the style of ceramic products - understood in terms of decoration, form, technology, and the function of the vessel - are influenced by a wide range of potential factors, but these changes should be evaluated in a socio-cultural context. These factors include an availability of raw materials, a potter's preferences and expertise, local ceramic traditions and technology, work organization, or a demand for specific products. The style changes, as mentioned above, are a reflection/consequence of changes occurring in social relations within a given community, since their cultural communication is a field for creating an identity of a given group.

Manifesting one's identity may be achieved in various ways, by a reception of new cultural patterns and adapting to a new situation, or rejecting any innovation, or assimilating only selected details while maintaining traditional elements.

In the case of ceramics, one of the ways to manifest one's individuality and identity could have been continued usage of traditional technology and style, i.e., the existing cultural patterns, despite the socio-political transformations, also observed in ceramics. In such a case, intentional refusal to adopt a foreign tradition may suggest support for the existing system and order, while expressing resistance to innovation prompted by a sense of threat to the group, which thereby illustrates a desire to maintain the status quo. An illustration of such a phenomenon is the introduction of a new technology of completely wheel-turned ceramics in the settlement centre in Międzyrzecz, where the process was different. The completely wheel-turned vessels registered only in the assemblages from the $2^{\text {nd }}$ half of the $10^{\text {th }}$ cent., where they occur in the amount of about $3 \%$ and in the $2^{\text {nd }}$ half of the $11^{\text {th }}$ century they reach a share of about $70 \%$ (Zamelska-Monczak 2015, 281-282). In comparison with the neighbouring northern and central Greater Poland or Pomerania, these changes take place much later, because in these areas vessels completely turned on the wheel appear in the $1^{\text {st }}$ half of the $10^{\text {th }}$ century in the amount of 3 to $35 \%$, and then in the $2^{\text {nd }}$ half of the $10^{\text {th }}$ century there is an increase in the number of these vessels to $45-55 \%$, and in the $1^{\text {st }}$ half of the $11^{\text {th }}$ century they totally dominate the ceramics assemblages (Kara 2009, 257-258). The rhythm of changes in the implementation of new technology observed in Międzyrzecz relates more to the areas located on the left bank of the Odra. In the Lower Lusatian zone, completely wheel-turned vessels appear in assemblages dating to the $3^{\text {rd }}$ quarter of the $10^{\text {th }}$ century, and then their amount increases, at first quite slowly, to become the main component of assemblages only in the mid- $11^{\text {th }}$ century (Biermann 2000, 280). In the middle Elbe region, completely wheel-turned ceramics have appeared in small quantities from the middle of the $10^{\text {th }}$ century and it reaches high attendance in the $11^{\text {th }}$ century assemblages (Biermann 2001, 349). Such a rhythm of changes corresponds best to the areas of the Tornow-Klenica zone with which Międzyrzecz was associated from the beginning of its foundation at the end of the $9^{\text {th }}$ century. What is important, this occurs despite the inclusion of Międzyrzecz into the structures of the Piast state (Zamelska-Monczak 2017, 22).

The communities living in the north-eastern part of Lower Silesia and the south-eastern part of Greater Poland manifested their identity in a different way. They preferred heavily decorated zoned vessels with extended ornamental compositions giving the pots an individual character. The presence of transitional vessels in the assemblages proves the local nature of the production of zoned ones. Zoned ceramics within the places located in the centre of the Piast state did not receive complete approval, and simultaneously, vessels of a different style were manufactured, which in the fourth quarter of the $10^{\text {th }}$ century began to become an identifier for these communities. 
5. To explain the differentiation of zoned ceramics, to define the influences from specific areas or centres or to ultimately recognize it as a product of the local community, created as a product of independent experience, a new research method should be applied. Due to the fact that in the analyzed area it is necessary to regard the use of local clay raw material and a mineral temper in the production of pots, specialist (archaeometric) analyzes of ceramics may become an argument in further research. This has already been pointed out by P. Rzeźnik (1997, 127): Only in the case of clear distinctiveness in terms of a clay fabric, manufacturing technique, general outline, and micro-details [emphasized by J. K. and K. Z-M.] of a form and ornamentation, a given product may be considered an import, i.e., a product of a foreign cultural environment. This can be approached as a research postulate in further studies on zoned ceramics. It's said that the devil is in the details - and this holds true in the case of studies on zoned vessels, in the micro-details of the technique for making vessels and their ornamentation.

\section{References}

Balcárková, A. - Dresler, P. - Macháček, J. 2017: Povelkomoravská a mladohradištní keramika v prostoru dolního Podyjí. Brno: Filozofická fakulta, Masarykova univerzita.

Biermann, F. 2000: Slawische Besiedlung zwischen Elbe, Neiße und Lubsza. Archäologische Studien zum Siedlungswesen und zur Sachkultur des frühen und hohen Mittelalters. Ergebnisse und Materialien zum DFG-Projekt "Germanen - Slawen - Deutsche". Schriften zur Archäologie der germanischen und slawischen Frühgeschichte, Band 5. Universitätsforschungen zur prähistorischen Archäologie, Band 65. Bonn: Dr. Rudolf Habelt GMBH.

Biermann, F. 2019: Die Zeitstellung slawischer Keramik in Vorpommern und Ostmecklenburg nach dendrochronologischen Daten. In: H.-G. Stephan ed., Keramik in Norddeutschland. Hallesche Beiträge zur Archäologie des Mittelalters 3, Langenweißbach: Beier \& Beran, 21-36.

Biermann, F. ed. 2001: Pennigsberg - Untersuchungen zu der slawischen Burg bei Mittelwalde und zum Siedlungswesen des $7 / 8$ bis 12. Jahrhunderts am Teltow und im Berliner Raum. Beiträge zur Ur- und Frühgeschichte Mitteleuropas 26. Weißbach: Beier \& Beran.

Biermann, F. - Kieseler, A. - Nowakowski, D. 2014: Grodzisko plemienne w Chobieni gm. Rudna w świetle badań archeologicznych. In: K. Chrzan et al. eds., Funkcje grodów w państwach wczesnośredniowiecznej Europy Środkowej. Społeczeństwo, gospodarka, ideologia, Wrocław - Głogów: Instytut Archeologii i Etnologii PAN - Państwowa Wyższa Szkoła Zawodowa w Głogowie, 269-333.

Brzostowicz, M. 2002: Bruszczewski zespół osadniczy. Poznań: Wydawnictwo Poznańskiego Towarzystwa Przyjaciół Nauk.

Bubeník, J. - Meduna, P. 1994: Zur frühmittelalterlichen Keramik in Nord-West-Böhmen. In: Č. Staňa ed., Slawische Keramik in Mitteleuropa vom 8. bis zum 11. Jahrhundert. Terminologie und Beschreibung. Kolloquium Mikulčice, 25.-27. Mai 1993. Internationale Tagungen in Mikulčice 1, Brno: Archäologisches Institut der Akademie der Wissenschaften der Tschechischen Republik, 183-192.

Buko, A. 1999: Wczesnośredniowieczna aglomeracja sandomierska. Początki i podstawy rozwoju. In: S. Moździoch ed., Centrum i zaplecze we wczesnośredniowiecznej Europie Środkowej, Wrocław: Instytut Archeologii i Etnologii PAN Oddział we Wrocławiu, 197-206.

Chudziak, W. 1991: Periodyzacja rozwoju wczesnośredniowiecznej ceramiki z dorzecza dolnej Drwęcy. Toruń: Uniwersytet Mikołaja Kopernika - Instytut Archeologii i Etnografii.

Cnotliwy, E. - Leciejewicz, L. - Łosiński, W. eds. 1983: Szczecin we wczesnym średniowieczu. Wzgórze Zamkowe. Wrocław - Warszawa: Zakład Narodowy im. Ossolińskich.

Dworaczyk, M. 2008: Wczesnośredniowieczne garncarstwo południowego wybrzeża Bałtyku - przykład szczeciński. In: M. Bogacki et al. eds., Kultura ludów Morza Bałtyckiego 1, Starożytność i średniowiecze, Toruń: Wydawnictwo Adam Marszałek, 269-283.

Dymaczewska, U. 1970: Ceramika wczesnośredniowieczna z Santoka, powiat Gorzów Wlkp. Slavia Antiqua $16,145-214$. 
Dziedzuszycki, W. 1972: Ceramika z wczesnośredniowiecznego Kaszowa w pow. milickim. Archeologia Polski 17, 391-444.

Dziedzuszycki, W. 1982: Wczesnomiejska ceramika kruszwica w okresie od 2 połowy X w. do połowy XIV w. Wrocław - Warszawa: Zakład Narodowy im. Ossolińskich.

Hansen, M.-H. 2006: Polis. An Introduction to the Ancient Greek City-State. Oxford - New York: Oxford University Press.

Hensel, W. 1950: Studia i materiały do osadnictwa Wielkopolski wczesnohistorycznej 1. Poznań: Polskie Towarzystwo Prehistoryczne.

Hensel, W. 1956: Z badań nad polska ceramiką wczesnośredniowieczną. Sprawozdania Archeologiczne 2, 160-167.

Hensel, W. 1960: Studia i materiały do osadnictwa Wielkopolski wczesnohistorycznej 3. Poznań: Państwowe Wydawnictwo Naukowe.

Hensel, W. 1971: Archeologia i prahistoria. Studia i szkice. Wrocław etc.: Zakład Narodowy im. Ossolińskich Wydawnictwo Polskiej Akademii Nauk.

Hilczer-Kurnatowska, Z. - Kara, M. 1994: Die Keramik vom 9. bis zur Mitte des 11. Jahrhunderts in Großpolen. In: Č. Staňa ed., Slawische Keramik in Mitteleuropa vom 8. bis zum 11. Jahrhundert. Terminologie und Beschreibung. Kolloquium Mikulčice, 25.-27. Mai 1993. Internationale Tagungen in Mikulčice 1, Brno: Archäologisches Institut der Akademie der Wissenschaften der Tschechischen Republik, 121-141.

Hilczerówna, Z. 1960: Wczesnośredniowieczne grodzisko w Daleszynie (stan. 2) w pow. gostyńskim. Poznań: Wydawnictwo Poznańskiego Towarzystwa Przyjaciół Nauk.

Hilczerówna, Z. 1967: Dorzecze górnej i środkowej Obry od VI do początków XI wieku. Wrocław etc.: Zakład Narodowy im. Ossolińskich.

Hołowińska, Z. 1956: Wczesnośredniowieczne grodzisko w Bonikowie, w powiecie kościańskim. Wyniki badań z lat 1951-1953. Poznań: Państwowe Wydawnictwo Naukowe.

Hołubowicz, W. 1957: Z badań nad wczesnośredniowieczną ceramiką z grodziska w Strachowie. Archeologia Śląska 1, 173-184.

Iwanicka-Pinkosz, B. 2000: Sprawozdanie z ratowniczych badań archeologicznych wczesnośredniowiecznej osady w miejscowości Osetno, stan. 18, gm. Góra, byłe woj. leszczyńskie. Wielkopolskie Sprawozdania Archeologiczne 5, 85-98.

Jaworski, K. - Lisowska, E. - Pankiewicz, S. - Stanisławski, B. 2013: Artefacts of Scandinavian origin from the Cathedral Island (Ostrów Tumski) in Wrocław. In: S. Moździoch et al. eds., Scandinavian Culture in Medieval Poland, Wrocław: Institute of Archaeology and Ethnology on the Polish Academy of Sciences - Centre for Late Antiquity and Early Medieval Studies, 279-307.

Kara, M. 2002: Osadnictwo ludności pomorskiej i wieleckiej w państwie pierwszych Piastów w świetle znalezisk nekropolicznych z terenu Wielkopolski. Slavia Antiqua 43, 45-96.

Kara, M. 2006: Nowe w archeologii Wielkopolski wczesnośredniowiecznej - 15 lat później. In: W. Chudziak S. Moździoch eds., Stan i potrzeby badań nad wczesnym średniowieczem w Polsce - 15 lat później, Toruń: Uniwersytet Mikołaja Kopernika - Instytut Archeologii i Etnografii, 207-244.

Kara, M. 2009: Najstarsze państwo Piastów - rezultat przełomu czy kontynuacji? Studium archeologiczne. Poznań: Instytut Archeologii i Etnologii PAN.

Kara, M. - Krapiec, M. - Teske, G. 2006: Wyniki badań archeo-dendrochronologicznych wybranych grodzisk wczesnośredniowiecznych z terenu historycznej Wielkopolski, przeprowadzonych w 2005 roku. Fontes Archaeologici Posnanienses 42, 125-144.

Kaźmierczyk, J. 1965: Z badań nad grodami i miastami wczesnego średniowiecza na Śląsku. Archeologia Polski 10, 655-700.

Kiarszys, G. - Kolenda, J. 2017: Wczesnośredniowieczne grodziska w krajobrazie Doliny Baryczy. Przyczynek do studiów nad przemianami osadniczymi. Śląskie Sprawozdania Archeologiczne 59, 93-126.

Kihl-Byczko, E. 1965: Badania ratunkowe na stan. 1 w Dusinie w pow. gostyńskim w roku 1955. Przegląd Archeologiczny 17, 207-217.

Knorr, H.-A. 1937: Die slawische Keramik zwischen Elbe und Oder. Mannus Bücherei 58 Leipzig: Verlag Curt Kabitzsch.

Kobylińska, U. 1980: Problemy, metody i implikacje amerykańskiej „socjologii ceramiki”. Archeologia Polski 25, 193-203.

Kobylińska, U. - Kobyliński, Z. - Bagiński, B. - Bojanowski, M. 2020: Early medieval pottery of the Menkendorf-Szczecin type in the light of the laboratory ceramological research. Archaeologica Hereditas. Studies in archaeological ceramology 17, 85-269. 
Kolenda, J. 2008: Wczesnośredniowieczny Milicz w świetle wykopalisk. In: J. Kolenda ed., Milicz. Clavis Regni Poloniae. Gród na pograniczu, Wrocław: Instytut Archeologii i Etnologii PAN Oddział we Wrocławiu, 9-63.

Kolenda, J. 2011: Wczesnośredniowieczne osadnictwo grodowe pogranicza Śląska i Wielkopolski w świetle analiz dendrochronologicznych. In: M. Rębkowski - S. Rosik eds., Populi Terrae Marisque, Wrocław: Wydawnictwo Chronicon, 41-65.

Kolenda, J. -Zamelska-Monczak, K. 2020: Wczesnośredniowieczna wytwórczość ceramiczna z północnowschodniej części Dolnego Śląska. In: K. Chrzan et al. eds., Ceramika i szkło w badaniach interdyscyplinarnych, Wrocław: Instytut Archeologii i Etnologii PAN, Ośrodek Badań nad Kulturą Późnego Antyku i Wczesnego Średniowiecza, 17-43.

Kostrzewski, J. 1949: Kultura prapolska. Poznań: Instytut Zachodni.

Kotková, M. 2008: Keramik des Zabrušaner Kreises als Quelle für die Kontakte zwischen Sachsen und Nordwestböhmen im Frühmittelalter. Arbeits- und Forschungsberichte zur sächsischen Bodendenkmalpflege 48/49 (2006/2007), 139-153.

Kotková, M. 2009: Keramik als Beispiel für Kulturtransfer. Bemerkungen zu den Kontakten zwischen Sachsen und Nordwestböhmen aufgrund der frühmittelalterlichen Keramik. In: A. Klammt -S. Rossignol eds., Mittelalterliche Eliten und Kulturtransfer östlich der Elbe. Interdisziplinäre Beiträge zu Archäologie und Geschichte im mittelalterlichen Ostmitteleuropa, Göttingen: Universitätsverlag Göttingen, $55-68$.

Kotková, M. - Lange, J.-M. 2010: Beziehungen zwischen Nordwestböhmen und dem sächsischen Elbtal im frühen Mittelalter anhand der Keramik des Zabrušaner Kreise. Zeitschrift für Archäologie des Mittelalters $38,43-83$.

Kouřil, P. - Gryc, J. 2018: Early medieval stronghold in Opava-Kylešovice and its importance for the understanding of the Silesian region in the tenth-eleventh centuries. In: P. Kouřil - R. Procházka eds., Moravian and Silesian Strongholds of the Tenth and Eleventh Centuries in the Context of Central Europe, Brno: The Czech Academy of Sciences, Institute of Archaeology, 185-213.

Krysztofiak, T. 2005: Palatium w Gieczu - archeologiczne podstawy datowania reliktów. In: J. Gadomski et al. eds., Lapides viventes. Zaginiony Kraków wieków średnich. Księga dedykowana Profesor Klementynie Żurowskiej, Kraków: Wydawnictwo Uniwersytetu Jagiellońskiego, 293-309.

Kurnatowska, Z. 2008: Początki i rozwój państwa. In: M. Kobusiewicz ed., Pradzieje Wielkopolski. Od epoki kamienia do średniowiecza, Poznań: Instytut Archeologii i Etnologii PAN, 297-395.

Kurnatowska, Z. 2009: Wielkopolska południowa we wczesnym średniowieczu. In: I. Hildebrandt-Radke et al. eds., Zapis działalności człowieka w środowisku przyrodniczym, Poznań: Bogucki Wydawnictwo Naukowe, 85-87.

Lodowski, J. 1972: Sądowel we wczesnym średniowieczu. Wrocław etc.: Zakład Narodowy im. Ossolińskich.

Lodowski, J. 1980: Grodzisko wczesnośredniowieczne w Strachowie, gm. Sobótka, woj. Wrocław. Sprawozdania Archeologiczne 32, 207-225.

Lastowiecki, M. 1989: Stratygrafia i chronologia Ostrowa Lednickiego. In: Studia Lednickie 1, Lednogóra: Muzeum Pierwszych Piastów na Lednicy, 17-70.

Łosiński, W. 1972: Początki wczesnośredniowiecznego osadnictwa grodowego w dorzeczu dolnej Parsęty. Wrocław etc.: Zakład Narodowy im. Ossolińskich - Wydawnictwo Polskiej Akademii Nauk.

Łosiński, W. 1996: Próba nowego spojrzenia na dzieje wczesnośredniowiecznego Szczecina. In: E. Wilgocki et al. eds., 50 lat archeologii polskiej na Pomorzu Zachodnim, Szczecin: Stowarzyszenie Naukowe Archeologów Polskich, Oddział w Szczecinie, 131-145.

Łosiński, W. 2008: Pomorze Zachodnie we wczesnym średniowieczu. Studium Archeologiczne. Poznań: Instytut Archeologii i Etnologii PAN.

Macháček, J. 2001: Studie k velkomoravské keramice. Metody, analýzy a syntézy, modely. Brno: Masarykova univerzita.

Mazuch, M. 2013: Velkomoravské keramické okruhy a tzv. mladší velkomoravský horizont v Mikulčicích. Brno: Archeologický ústav Akademie věd České republiky.

Meduna, P. 2015: Zabrušanská keramika v dnešním Sasku jako historická otázka. Archeologie ve středních Čechách 19, 327-350.

Messal, S. 2011: Zur slawischen Keramik des Typs "Glienke”. In: F. Biermann et al. eds., Der Wandel um 1000. Beiträge der Sektion zur slawischen Frühgeschichte der 18. Jahrestagung des Mittel- und Ostdeutschen Verbandes für Altertumsforschung in Greifswald, 23. bis 27. März 2009, Langenweissbach: Beier \& Beran, 347-359. 
Messal, S. 2015: Glienke. Eine slawische Burg des 9. und 10. Jahrhunderts im östlichen Mecklenburg. Frühmittelalterliche Archäologie zwischen Ostsee und Mittelmeer, Band 5. Wiesbaden: Reichert Verlag.

Michálek, J. - Lutovský, M. 2000: Hradec u Němětic. Sídlo halštatské a raně středověké nobility v česko-bavorském kontaktním prostoru 1-3. Strakonice - Praha: Muzeum středního Pootaví etc..

Motylewska, I. 2010-2012: Grodzisko w Czerchowie w świetle badań archeologicznych. Prace i Materiały Muzeum Archeologicznego i Etnograficznego w Łodzi 45, 289-352.

Niesiołowska, A. - Perzyńska, M. - Żak, J. 1960: Badania na posesji Ostrów Tumski 13 w latach 1950-1953. In: W. Hensel ed., Poznań we wczesnym średniowieczu 2, Wrocław etc.: Zakład Narodowy im. Ossolińskich, 67-219.

Neustupný, E. 1948: Přispěvek k datování hradištní keramiky v Polabí. Slavia Antiqua 1, 397-434.

Pałubicka, A. 1975: Grodzisko wklęsłe w Bninie, pow. śremski. In: J. Żak ed., Materiały do studiów nad osadnictwem bnińskim. Grodzisko wklęsłe, Poznań: Wydawnictwo Naukowe UAM, 11-148.

Pankiewicz, A. 2012: Relacje kulturowe południowego Śląska i północnych Moraw i Czech w IX-X wieku w świetle źródeł ceramicznych. Acta Universistatis Wratislaviensis No 3372. Wrocław: Wydawnictwo Uniwersytetu Wrocławskiego.

Pankiewicz, A. 2020: Pottery at the Borderland. Southern influence in Silesia and Lesser Poland in 9th and 10th century. Wrocław: Yellow Point Publications.

Pankiewicz, A. - Rodak, S. 2019: Łozina - wczesnośredniowieczny kompleks osadniczy na przedpolu Wrocławia. Problem chronologii i funkcji. Śląskie Sprawozdania Archeologiczne 61, 85-111.

Paternoga, M. 2003: Stanowisko nr 1 we Wszemirowie, pow. Trzebnica, w świetle dawniejszych i najnowszych badań. Śląskie Sprawozdania Archeologiczne 45, 157-174.

Paternoga, M. - Rzeźnik, P. - Siemianowska, S. 2017: Naczynia Solniki-Lipowiec. Lokalna grupa ceramiki całkowicie obtaczanej w północnej części Śląska. In: S. Siemianowska et al. eds.,Ceramika i szkło w archeologii i konserwacji, Wrocław: Instytut Archeologii i Etnologii PAN - Katedra Konserwacji i Restauracji Ceramiki i Szkła Akademii Sztuk Pięknych im. Eugeniusza Gepperta we Wrocławiu, 83-105.

Poláček, L. 1994: Zum Stand der Erkenntnis der frühmittelalterlichen Keramik aus dem Burgwall "Valy" bei Mikulčice. In: Č. Staňa ed., Slawische Keramik in Mitteleuropa vom 8. bis zum 11. Jahrhundert. Terminologie und Beschreibung. Kolloquium Mikulčice, 25.-27. Mai 1993. Internationale Tagungen in Mikulčice 1, Brno: Archäologisches Institut der Akademie der Wissenschaften der Tschechischen Republik, 207-217.

Princová-Justová, J. 1994: Die burgwallzeitliche Keramik aus Libice nad Cidlinou. In: Č. Staňa ed., Slawische Keramik in Mitteleuropa vom 8. bis zum 11. Jahrhundert. Terminologie und Beschreibung. Kolloquium Mikulčice, 25.-27. Mai 1993. Internationale Tagungen in Mikulčice 1, Brno: Archäologisches Institut der Akademie der Wissenschaften der Tschechischen Republik, 193-205.

Procházka, R. 2017: Hrad Přerov v raném středověku (9.-11. století) a počátky mladohradištní hmotné kultury. Archeologický výzkum na Horním náměstí. Brno: Archeologický ústav Akademie věd České republiky.

Profantová, N. 2000: Slovanské výšinné sídliště z Třebovle, okr. Kolín. K problému napodobování cizích předloh v keramice. Archeologické rozhledy 52, 647-664.

Rice, P. M. 2015: Pottery Analysis. A Sourcebook. Second Edition. Chicago - London: The University of Chicago Press.

Rusó, A. 1991: Příspěvek k poznání slovanského hradiště v Zabrušanech. Teplice: Krajské muzeum Teplice.

Rusó, A. 1994: Statistické hodnocení keramiky ze Zabrušan a Chlumce. Památky archeologické 85, 34-81.

Rzeźnik, $P$. 1995a: K výzkumu keramického importu v raně městské Vratislavi. Archaeologia historica 20, 589-600.

Rzeźnik, P. 1995b: Ceramika naczyniowa z Ostrowa Tumskiego we Wrocławiu w X-XI wieku. Poznań: Poznańskie Towarzystwo Przyjaciół Nauk.

Rzeźnik, P. 1997: Elementy południowe w ceramice śląskiej w IX-X wieku. In: K. Wachowski ed., Śląsk i Czechy a kultura wielkomorawska, Wrocław: Uniwersytet Wrocławski - Centrum Badań Śląskoznawczych i Bohemistycznych, 127-134.

Schoknecht, U. 1971: Probleme der Ravensburg bei Neubrandenburg. Bodendenkmalpflege in Mecklenburg 1970, 263-272.

Schuldt, E. 1956: Die slawische Keramik in Mecklenburg. Berlin: Akademie-Verlag.

Siemianowska, S. 2010: Typ Bruszczewo i dalkowsko-obrzańska grupa form naczyń wczesnośredniowiecznych. Uwagi w kwestii zasięgu występowania, chronologii oraz genezy. Śląskie Sprawozdania Archeologiczne 52, 203-222. 
Siemianowska, S. 2017: Bliska obcość. Ceramika jako identyfikator kontaktów handlowych i politycznych czy wspólnoty kultur wczesnośredniowiecznych zespołów osadniczych Słowiańszczyzny? Uwagi z perspektywy studiów nad dziesiątowieczną ceramiką z Obiszowa k. Głogowa. In: S. Siemianowska et al. eds. Ceramika i szkło w archeologii i konserwacji, Wrocław: Instytut Archeologii i Etnologii PAN Katedra Konserwacji i Restauracji Ceramiki i Szkła Akademii Sztuk Pięknych im. Eugeniusza Gepperta we Wrocławiu, 51-82.

Staňa, Č. 1994: Die Entwicklung der Keramik vom 8. bis zur Mitte des 11. Jahrhunderts in Mittelmähren. In: Č. Staňa ed., Slawische Keramik in Mitteleuropa vom 8. bis zum 11. Jahrhundert. Terminologie und Beschreibung, Kolloquium Mikulčice, 25.-27. Mai 1993. Internationale Tagungen in Mikulčice 1, Brno: Archäologisches Institut der Akademie der Wissenschaften der Tschechischen Republik, 265-294.

Stoksik, H. - Paternoga, M. 2009: Techno-stylistyczne kategorie ceramiki wczesnośredniowiecznej z północnych rejonów Śląska w świetle analiz fizykochemicznych. Szkło i Ceramika 60/3, 34-40.

Teske, G. 2000: Ze studiów nad osadnictwem grodowym w południowo-wschodniej Wielkopolsce. Slavia Antiqua 41, 107-128.

Teske, G. 2005: Golina - wczesnośredniowieczny gród wielkopolski na Wysoczyźnie Kaliskiej. Archaeologia Historica Polona 15/2, 27-41.

Trzeciecki, M. 2009: Stare i nowe w garncarstwie wczesnośredniowiecznego Płocka. In: S. Moździoch ed., Stare i nowe w średniowieczu. Pomiędzy innowacją a tradycją, Wrocław: Instytut Archeologii i Etnologii PAN Oddział we Wrocławiu, 187-228.

Ván̆a, Z. 1951: Slovanské hradiště u Zabrušan. Archeologické rozhledy 3, 53-55, 58-60, 90, 95.

Váña, Z. 1961: Slovanská keramika zabrušanského typu v severozápadních Čechách. Památky archeologické 52, 465-475.

Wiessner, P. 1983: Style and Social Information in Kalahari San Projectile Points. American Antiquity 48, 253-276.

Wobst, M. 1977: Stylistic Behavior and Information Exchange. In: C.-E. Cleland ed., For the Director: Research Essays in Honor of James B. Griffin. Michigan Anthropological Papers 61, Ann Arbor: Museum of Anthropology, University of Michigan, 317-342.

Zamelska, K. 1995: Grodzisko w Poniecu (stanowisko 1), woj. leszczyńskie. In: Z. Kurnatowska ed., Z badań nad osadnictwem Wielkopolski południowej, Poznań: Wydawnictwo Poznańskiego Towarzystwa Nauk, 9-82.

Zamelska-Monczak, K. 2015: Ceramika naczyniowa z faz wczesnośredniowiecznych - podsumowanie. In: S. Kurnatowski ed., Międzyrzecz. Gród i zamek w wiekach IX-XIV. Wyniki prac wykopaliskowych z lat 1954-1961. Origines Polonorum 8, Warszawa: Fundacja na Rzecz Nauki Polskiej - Instytut Archeologii i Etnologii PAN - Trio, 279-286.

Zamelska-Monczak, K. 2017: Grody w Międzyrzeczu i Santoku we wczesnym średniowieczu - podobieństwa i różnice. In: T. Sawicki ed., Studia nad dawną Polska 5, Gniezno: Muzeum Początków Państwa Polskiego w Gnieźnie, 11-28.

Zamelska-Monczak, K. ed. 2019: Santok. Strażnica i klucz Królestwa Polskiego. Wyniki badań z lat 1958-1965. Origines Polonorum 13. Warszawa: Instytut Archeologii i Etnologii PAN.

JUSTYNA KOLENDA, Ośrodek Badań nad Kulturq Późnego Antyku i Wczesnego Średniowiecza IAE PAN, ul. Więzienna 6, PL-50-118 Wrocław; jko@arch.pan.wroc.pl

https://orcid.org/0000-0002-0177-2550

KINGA ZAMELSKA-MONCZAK, Ośrodek Studiów Pradziejowych i Średniowiecznych IAE PAN, ul. Rubież 46, PL-61-612 Poznań; kinga.zamelska@iaepan.poznan.pl

https://orcid.org/0000-0002-5752-1451 